\title{
Effect of Androgens on Sexual Differentiation of Pituitary Gamma-Aminobutyric Acid Receptor Subunit GABA Expression
}

\author{
María S. Bianchi ${ }^{a}$ Paolo N. Catalano a,b María M. Bonaventura ${ }^{a}$ \\ Patricia Silveyra ${ }^{a}$ Bernhard Bettler ${ }^{c}$ Carlos Libertun ${ }^{a, b}$ \\ Victoria A.R. Lux-Lantos ${ }^{a}$ \\ a Instituto de Biología y Medicina Experimental-CONICET, and 'bepartment of Physiology, School of Medicine, \\ University of Buenos Aires, Buenos Aires, Argentina; ${ }^{\mathrm{C} D e p a r t m e n t}$ of Clinical-Biological Sciences, \\ Biozentrum/Pharmazentrum, University of Basel, Basel, Switzerland
}

\section{Key Words}

Gamma-aminobutyric acid · Gamma-aminobutyric acid receptors - Gonadal steroids - Sex differentiation · Gonadotropins · Sex dimorphism • Excitatory amino acid neurotransmitters

\begin{abstract}
Previous work demonstrated a sexually dimorphic ontogenic expression of $\gamma$-aminobutyric acid receptors $\left(G A B A_{B} R\right)$ in rat pituitary. As sex steroids determine sexspecific expression patterns, we now studied the effect of sex hormones on pituitary $G A B A_{B} R$ expression. $\mathrm{GABA}_{B} R$ subunits, measured by Western blot and by semi-quantitative RT-PCR and luteinizing hormone (LH), follicle-stimulating hormone (FSH) and testosterone measured by RIA were determined in two experimental designs: First experimental design: 8- and 15-day-old females $(8 \mathrm{~F}, 15 \mathrm{~F})$; $8 \mathrm{~F}$ and $15 \mathrm{~F}$ treated with $100 \mu \mathrm{g}$ testosterone propionate (TP) on day 1 of life (8F100TP, 15F100TP), 8- and 15-day-old males (8M, 15M) and 8M and $15 \mathrm{M}$ castrated on day 1 ( $8 \mathrm{MC}, 15 \mathrm{MC})$. Second experimental design: 8-day-old female and male animals: $8 \mathrm{~F}$, 8F100TP, 8F treated with $1 \mu \mathrm{g} /$ day TP on days $1-4$ (8F1TP), 8F treated with the androgen antagonist Flutam-
\end{abstract}

\section{KARGER}

Fax +41613061234

E-Mail karger@karger.ch

www. karger.com
(C) 2004 S. Karger AG, Basel

0028-3835/04/0803-0129\$21.00/0

Accessible online at:

www. karger.com/nen ide (Flut: $2.5 \mathrm{mg} / 100 \mathrm{~g} \mathrm{BW}$ of pregnant mother on days E17-E23) (8F-Flut), 8M, 8MC, 8M treated with Flut as above (8M-Flut) and 8MC-Flut. In these animals, in addition, GABA, glutamate, aspartate and taurine were measured by HPLC in hypothalami and cortex. In the first set of experiments, $\mathrm{GABA}_{\mathrm{B} 1} \mathrm{R}$ mRNA/protein expression was higher in $8 \mathrm{~F}$ than in $15 \mathrm{~F}, 8 \mathrm{M}$ or $15 \mathrm{M}$. In $8 \mathrm{~F} 100 \mathrm{TP}$, $\mathrm{GABA}_{\mathrm{B} 1} \mathrm{R}$ mRNA/protein decreased to male levels. TP treatment did not alter $\mathrm{GABA}_{\mathrm{B} 1} \mathrm{R}$ expression in $15 \mathrm{~F}$.

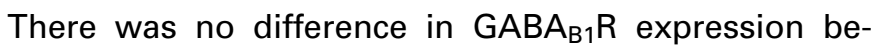
tween $8 \mathrm{M}$ and $15 \mathrm{M}$ and neonatal castration did not modify its expression. In the second set of experiments, TP $(1 \mu \mathrm{g})$ or Flut did not modify $\mathrm{GABA}_{\mathrm{B} 1} \mathrm{R}$ in $8 \mathrm{~F}$, while $100 \mu \mathrm{g}$ TP continued to decrease $G_{A B A_{B 1}} R$ expression. In $8 M$, Flut, alone or with castration, increased $\mathrm{GABA}_{\mathrm{B} 1} \mathrm{R}$ mRNA/ protein expression to 8F. Hypothalamic GABA content followed the same pattern as pituitary $G A B A_{B} R$ expression in 8-day-old animals, suggesting a cross-regulation. With regard to hormonal levels, $100 \mu \mathrm{g}$, but not $1 \mu \mathrm{g}$ TP altered gonadotropins at 8 days, although both treatments effectively androgenized females as evidenced by lack of cycling. We conclude that androgens, acting preand postnatally, decrease pituitary $G_{A B A} R$ subunit expression.

Copyright $@ 2004$ S. Karger AG, Basel
Carlos Libertun

V. de Obligado 2490

C1428ADN Buenos Aires (Argentina)

Tel + +54 1147832869, Fax +541147862564

E-Mail libertun@dna.uba.ar 


\section{Introduction}

Gamma-aminobutyric acid (GABA) participates in the control of hypophyseal secretion acting in the central nervous system (CNS) and directly on the pituitary $[1,2]$. Pituitary GABA derives from tuberoinfundibular GABA, intermediate pituitary lobe GABAergic axons, other hypothalamic GABAergic systems and local synthesis $[3,4]$.

GABA acts on ionotropic $\mathrm{GABA}_{\mathrm{A} / \mathrm{C}}$ and metabotropic $\mathrm{GABA}_{\mathrm{B}}$ receptors. $\mathrm{GABA}_{\mathrm{B}} \mathrm{Rs}$ are G-protein-coupled receptors, in which heterodimeric assembly of a $\mathrm{GABA}_{\mathrm{B}(1)}$ and a $\mathrm{GABA}_{\mathrm{B}(2)}$ subunit confers functionality [5-7]. Initially, $\mathrm{GABA}_{\mathrm{B}(1 \mathrm{a})}$ and $\mathrm{GABA}_{\mathrm{B}(\mathrm{lb})}$ splice variants of the $\mathrm{GABA}_{\mathrm{B}(1)}$ gene were isolated [8], additional variants are proposed $[9,10]$.

Functional $\mathrm{GABA}_{\mathrm{B}} \mathrm{Rs}$ are also expressed in peripheral tissues $[11,12]$. We have previously described that pituitary $\mathrm{GABA}_{\mathrm{B}} \mathrm{Rs}$ are coupled to the same CNS signaling pathways [13]. In addition, $\mathrm{GABA}_{B}$ Rs participate in the regulation of prolactin and gonadotropin secretion acting both centrally and directly on the gland in developing and adult rats [14-17]. The presence of $\mathrm{GABA}_{B}$ receptors in somatotropes has also been demonstrated $[4,18]$.

Both GABA and GABA biosynthetic enzymes as well as $\mathrm{GABA}_{\mathrm{A}}$ and $\mathrm{GABA}_{\mathrm{B}}$ receptors display particular ontogenic distributions in the CNS, including critical areas involved in pituitary control [19-23]. In addition, GABA plays an important neurodifferentiative role along development [24]. Various ontogenic $\mathrm{GABA}_{\mathrm{B}} \mathrm{R}$ expression patterns have been described $[21,25,26]$; in some cases a switch in subunit expression was observed [26, 27]. Previously we reported particular pituitary $G_{A B A} R$ ontogenic patterns [28]. $\mathrm{GABA}_{\mathrm{B}(1 \mathrm{a})}$, the main subunit expressed in the pituitary, decreases throughout postnatal development in both sexes and is more abundant in female than in male infantile rats.

Several brain-controlled functions differ between males and females, the most obvious being those involved in reproductive physiology [29-31]. Sexually dimorphic differences in neuronal connections and brain structures are the result of the irreversible action of gonadal hormones during a sensitive period [31, 32]. In rats, androgens secreted both prenatally by fetal testis (E-18) and early postnatally [33] permanently masculinize and defeminize neural substrates, controlling sexually dimorphic brain functions, behavior and genital morphology [29, 30, $34,35]$. Conversely, steroid effects on female gonadotropin patterns and sexual behavior are primarily postnatal [31]. These sexually divergent anatomical and behavioral characteristics are the consequence of changes arising from turning on or shutting off gene expression, e.g. reflected by differences in receptor or enzyme levels [3638].

Due to the clear sexually dimorphic expression of $\mathrm{GABA}_{\mathrm{B}} \mathrm{R}$ at early stages of development in the pituitary and to the pivotal role of sex steroids in determining sexspecific expression patterns, the aim of the present work was to study the effect of sexual differentiation on $\mathrm{GABA}_{\mathrm{B}} \mathrm{R}$ expression in this gland.

\section{Materials and Methods}

\section{Animals}

Male and female Sprague-Dawley rats (200-250 g) from the Instituto de Biología y Medicina Experimental colony were housed in groups in an air-conditioned room, with lights on from 07.00 to $19.00 \mathrm{~h}$. They were given free access to laboratory chow and tap water. All studies on animals were performed according to protocols for animal use, approved by the Institutional Animal Care and Use Committee (IBYME-CONICET) that follows NIH guidelines.

\section{First Experimental Design}

Female rats were mated on proestrus and day 1 of gestation was considered when a vaginal sperm plug was noted the next day. On the day of birth (designated day 1) the sex of the pups was determined. For these studies, 8- and 15-day-old pups were selected because, from previous observations [28], at these ages we expected to find high ontogenic levels of $\mathrm{GABA}_{\mathrm{B} 1}$ receptor expression in both sexes and the sexual difference in expression levels observed before [28]. In addition, these ages were selected to be able to use the lowest number of animals possible, as several pituitaries were necessary for each Western blot sample (see below). Within $24 \mathrm{~h}$ of birth, pups were randomly assigned to treatment groups. The females were injected subcutaneously (s.c.) on the day of birth either with $0.05 \mathrm{ml}$ castor-oil vehicle (8- and 15-day-old control females: $8 \mathrm{~F}$ and $15 \mathrm{~F}$ ) or with a single injection of $100 \mu \mathrm{g}$ of testosterone propionate (TP) in $0.05 \mathrm{ml}$ castor oil [39] (neonatally androgenized females: 8F100TP and 15F100TP). Males were either castrated neonatally on day 1 (8MC and $15 \mathrm{MC})$ or sham castrated (control males: $8 \mathrm{M}$ and $15 \mathrm{M}$ ). Neonatal castration was performed under cold anesthesia. Pups were kept with their mothers until the day of the experiment. Animals were killed at 8 or 15 days of age by decapitation, early in the morning (09.00-10.00 h) to avoid circadian variations. Serum, anterior hypophysis, hypothalami and cortex were collected and frozen at $-70^{\circ} \mathrm{C}$.

\section{Second Experimental Design}

In this case only 8-day-old animals were included, since the first experimental design showed that by 15 days of age animals had already attained adult, low levels of expression. Timed pregnant rats were daily injected s.c. with either $10 \%$ ethanol in castor oil (vehicle control) or Flutamide (Flut: an androgen receptor antagonist, $25 \mathrm{mg} /$ $\mathrm{kg}$ BW adjusted daily based on body weight, prepared by dissolving the drug first in absolute ethanol, where it dissolved completely, and then diluting it in castor oil), from day 17 of gestation until the day before delivery [40]. Within $24 \mathrm{~h}$ of birth, the sex of the pups was
130

Neuroendocrinology 2004;80:129-142
Bianchi/Catalano/Bonaventura/Silveyra/ Bettler/Libertun/Lux-Lantos 
determined. In the case of newborn pups from Flut-treated mothers, males were not readily distinguishable from females as all had clitoris, clitoral urethra and nipples. To distinguish between them, application of manual pressure to the abdomen resulted in immediate and reversible eversion of gubernacular cones, allowing the unequivocal distinction between male and females [41]. Gubernacular cones are malespecific, papilla-like structures growing in the abdominal inguinal region towards the end of prenatal life and are a prerequisite for postnatal testis descent; their development is not altered by flutamide treatment [41]. Newborn females, from vehicle-injected mothers, were injected s.c. with TP on day lof life (single dose of $100 \mu \mathrm{g}$ in $0.05 \mathrm{ml}$ castor oil: $8 \mathrm{~F} 100 \mathrm{TP}$ ), or received one daily injection of either $1 \mu \mathrm{g}$ TP in $0.05 \mathrm{ml}$ castor oil (8F1TP) or vehicle (8F: controls) on postnatal days 1-4 following the androgenization protocol described by McDonald and Doughty [42]. Newborn female pups from Flutinjected mothers were left without further treatment (8F-Flut). Newborn males from vehicle or Flut-injected mothers were either castrated (8MC or $8 \mathrm{MC}-$ Flut) or sham castrated (8M and $8 \mathrm{M}$-Flut) on the day of birth. Animals were killed at 8 days of age by decapitation, early in the morning, to avoid circadian variations. Serum, anterior hypophysis, hypothalami and cortex were collected and frozen at $-70^{\circ} \mathrm{C}$.

Group of control females (F), females injected with either $100 \mu \mathrm{g}$ TP (F100TP) or $1 \mu \mathrm{g}$ TP (F1TP), as in the second experimental design, were left to grow and were weaned on day 21 . Beginning on day 28 of age they were weighted and examined daily for vaginal opening. No animals belonging to the F100TP group showed vaginal opening. From days 40 through 75 of age, vaginal smears were obtained from both F1TP and F at least six times per week. Finally, animals from each treatment condition were killed by decapitation, at approximately 75 days of age, either early in the morning, around 9.00 a.m. or later in the afternoon, around 5.00 p.m. (F were killed on proestrous) and trunk blood was collected.

Regular cycles were defined as the occurrence of 3 consecutive 4-5-day cycles. The beginning of regular cycles in control females (F) was detected from 50 through 60 days of life. Anestrous, an indication of the loss of the capacity of cyclic release of gonadotropins in amounts enough for ovulation, was defined as the presence of cornified smears, similar to estrous vaginal smears (squamous epithelial cells), during at least fifteen consecutive days. 'Pin hole' vaginal opening [42] was defined as the occurrence of a little orifice either not allowing or allowing partial intrusion of the plastic pipette to take a sample of vaginal fluid.

\section{Drugs}

Testosterone propionate and flutamide (2-methyl-N-[4-nitro-3(trifluoromethyl)-phenyl]propanamide), an androgen receptor antagonist, were acquired from Sigma-Aldrich, St. Louis, Mo., USA.

\section{Membrane Preparation}

Anterior pituitaries were collected and the membrane fraction was isolated as previously described [28]. Briefly, pituitaries (10 pituitaries for each 8-day-old sample and 7 for each 15-day-old sample) were homogenized in 10 vol of ice-cold $0.32 \mathrm{M}$ sucrose, containing $1 \mathrm{~m} M \mathrm{MgCl}_{2}$ and $1 \mathrm{mM} \mathrm{K}_{2} \mathrm{HPO}_{4}$, with a glass/teflon homogenizer. Membranes were centrifuged at $750 \mathrm{~g}$, the pellet was resuspended and the centrifugation repeated. The supernatants were pooled and centrifuged at $18,000 \mathrm{~g}$ for $15 \mathrm{~min}$. The pellet was osmotically shocked, centrifuged at $39,000 \mathrm{~g}$, resuspended in $50 \mathrm{~m} M$ Tris- $\mathrm{HCl}$, $2.5 \mathrm{mM} \mathrm{CaCl} 2, \mathrm{pH} 7.4$ (10 vol/g of original tissue). Membranes were frozen at $-70^{\circ} \mathrm{C}$.

Sexual Differences in Pituitary GABA ${ }_{B}$

Receptors

\section{Western Blot Analysis}

Western blot analysis of $\mathrm{GABA}_{\mathrm{B}} \mathrm{R}$ subunits were performed as described by Bianchi at al [28]. Briefly, $40 \mu \mathrm{g}$ of pituitary membranes proteins measured by the Lowry method were subjected to $8 \%$ SDSPAGE. Proteins were transferred onto nitrocellulose by standard wet elctrophoretic transfer in a $0.2 \mathrm{M}$ phosphate buffer. Blots were blocked in NETG buffer $(150 \mathrm{~m} M \mathrm{NaCl} ; 5 \mathrm{~m} M$ EDTA; $50 \mathrm{~m} M$ Tris$\mathrm{HCl}, \mathrm{pH} 7.4 ; 0.05 \%$ Triton X-100; $0.25 \%$ gelatin) for $45 \mathrm{~min}$ at room temperature. $\mathrm{GABA}_{\mathrm{B} 1}$ subunit was detected by incubating for $45 \mathrm{~min}$ at room temperature with the antibody Ab174.1 (1:3,000), developed by Dr. Bettler [5], directed against the C-terminal epitopes of

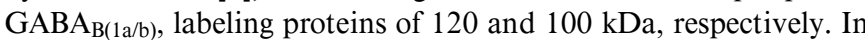
all immunoblotting experiments, a monoclonal antibody directed against $\alpha$-syntaxin $(1: 3,000)$ was used to ensure comparable protein load. Secondary antibody was peroxidase coupled $(1: 3,000)$. Blots were washed following each antibody incubation for 50 min with NETG. Detection of the antibody was performed using enhanced chemiluminescence Western blot analysis system (Western Blotting Chemiluminescence Luminol Reagent, Santa Cruz Biotechnology, Inc., Santa Cruz, Calif., USA). Quantification of immunoblots was performed with Imagequant soft.

\section{Amino Acidic Neurotransmitter Determination by HPLC}

Glutamate, GABA, aspartate and taurine were determined in hypothalami (limited anteriorly by the optic chiasma, laterally by the hypothalamic fissures, posteriorly by the mammillary bodies and in depth by the subthalamic sulcus, and including the preoptic-suprachiasmatic area [43] and frontoparietal cortex from: $8 \mathrm{~F}, 8 \mathrm{~F} 1 \mathrm{TP}$, 8F100TP, 8F-Flut, 8M, 8MC, 8M-Flut and 8MC-Flut. Amino acids were determined using the procedure previously described by Saller and Czupryna [44] with minor modifications. An HPLC system, which consisted of a Model 125 Programmable Solvent Module (Beckman Instruments, Fullerton, Calif., USA), a $5-\mu \mathrm{m}, 25 \mathrm{~cm} \times$ 4.6-mm Ultrasphere ${ }^{\circledR}$ ODS reversed-phased column (Beckman), a Model 166 Programmable UV Detector Module (254 nm) (Beckman) and System Gold ${ }^{\circledR}$ software (Beckman) was used. The mobile phase consisted of a water-acetonitrile mixture $(82: 18, \mathrm{v} / \mathrm{v})$ containing $0.15 \%(\mathrm{v} / \mathrm{v})$ phosphoric acid. Final treatment of standards and samples consisted of: the dansyl derivatives, placed in $1.5-\mathrm{ml}$ microfuge tubes, were evaporated to dryness in a Savant Speed-Vac concentrator (Savant Instruments, Holbrook, N.Y., USA) and the dried residues were vigorously resuspended in $200 \mu$ of mobile phase using a vortex mixer, placed in a ultrasonic bath and finally centrifuged at $13,000 \mathrm{~g}$ for $3 \mathrm{~min}$ to remove particulate matter before injecting $20-\mu l$ aliquots of the supernatants into the HPLC system.

\section{Hormone Dosage}

Serum LH and FSH were determined by RIA using kits obtained through NHPP, NIDDK and Dr. Parlow. Results were expressed in terms of $\mathrm{RP}_{3}$ rat $\mathrm{LH}$ and FSH standards. Assay sensitivities were $0.015 \mathrm{ng} / \mathrm{ml}$ for $\mathrm{LH}$ and $0.1175 \mathrm{ng} / \mathrm{ml}$ for FSH. Intra- and inter-assay coefficients of variation for LH were 7.2 and $11.4 \%$, respectively, and for FSH 8.0 and $13.2 \%$, respectively. Serum testosterone was determined by RIA using a specific antiserum kindly provided by Dr. G.D. Niswender, after ethyl-ether extraction. Labeled hormone was purchased from New England Nuclear. Assay sensitivity: lowest point in the testosterone standard curve was $12.5 \mathrm{pg}$, the lowest detectable concentration when extracting $150 \mu \mathrm{l}$ serum was $208.3 \mathrm{pg} /$ ml. Intra- and interassay coefficients of variation were 7.8 and $12.3 \%$, respectively. 
Fig. 1. Validation of semiquantitative RTPCR for $\mathrm{GABA}_{\mathrm{B} 1}$ receptor subunit and $\beta$ actin. Total RNA from pituitaries was reverse transcribed. A linear relationship was observed between the optical density of PCR products and (a) $\mu \mathrm{g}$ of RNA; (b) number of cycles when $0.5 \mu \mathrm{g}$ of RNA was reverse transcribed, and (c) $\mu \mathrm{l}$ of cDNA when $0.5 \mu \mathrm{g}$ of RNA was reverse transcribed and amplified at 36 and 20 cycles for $\mathrm{GABA}_{\mathrm{B} 1}$ receptor subunit and $\beta$-actin, respectively. A representative curve is shown in each case.
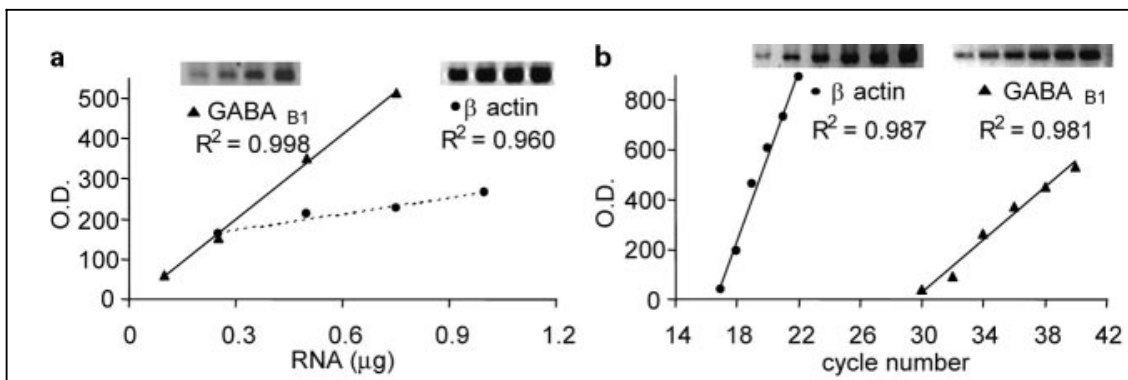

c

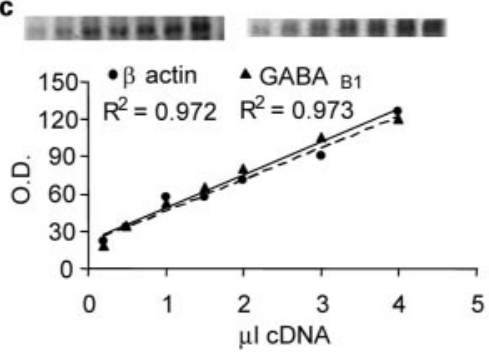

Total RNA Preparation and RT-PCR Analyses

Total RNA was obtained using the Trizol RNA isolation reagent (Invitrogen, Calif., USA) from fresh rat pituitaries from the same experimental groups. In the second experimental design, 8-day-old females treated with $1 \mu \mathrm{g}$ TP on days 1-4 and 8-day-old females treated in utero with Flut were not included, as these treatments did not modify $\mathrm{GABA}_{\mathrm{B}} \mathrm{R}$ expression evaluated by Western Blots or hormone levels (see 'Results'). The RNA concentration was determined based on absorbance at $260 \mathrm{~nm}$ and its purity was evaluated by the ratio of absorbencies at $260 \mathrm{~nm} / 280 \mathrm{~nm}(>1.8)$. RNA quality was assessed running random samples on denaturated gels. RNAs were kept frozen at $-70^{\circ} \mathrm{C}$ until analyzed.

Total RNA $(0.5 \mu \mathrm{g})$ was reverse-transcribed into cDNA using MMLV (Invitrogen) according to the manufacturer's instructions, primed with oligo(dT) $)_{15}$ (Biodynamics SRL, Argentina). In all RT reactions a negative control, lacking MMLV, was included.

PCR ( $2 \mu \mathrm{l}$ of RT reaction) consisted of a 5 -min hot start step followed by 36 cycles $\left(\mathrm{GABA}_{\mathrm{B} 1}\right)$ or 20 cycles ( $\beta$-actin) of denaturation at $94^{\circ} \mathrm{C}$ for $1 \mathrm{~min}$, annealing at $55^{\circ} \mathrm{C}$ for $1 \mathrm{~min}$ and extension at $72^{\circ} \mathrm{C} 1 \mathrm{~min}$; with a final extension for $10 \mathrm{~min}$ at $72^{\circ} \mathrm{C}$ after the last cycle. PCR amplifications were carried out using Taq DNA polymerase (Invitrogen-Life Technologies, USA) and specific oligonucleotide primers which were chosen to encompass exon-intron boundaries to avoid possible genomic DNA contamination. PCR reactions were performed following the Taq DNA polymerase manufacturer's instructions. The primers for $\mathrm{GABA}_{\mathrm{B} 1}$ subunit (Bio Synthesis, USA) did not distinguish between the splice variants $\mathrm{GABA}_{\mathrm{B}(1 \mathrm{a})}$ and $\mathrm{GABA}_{\mathrm{B}(1 \mathrm{~b})}$ and were synthesized based on the sequences described by Schuler et al. [45], amplifying a theoretical fragment of $254 \mathrm{bp}$ from mRNA and of $690 \mathrm{bp}$ from genomic DNA. The primers for $\beta$-actin (Invitrogen-Life Technologies, USA) were synthesized following a published sequence [46]: forward: 5'-GGAAATCGTGCGTGACAT-3'; reverse: 5'-GGAAGGTGGACAGTGAGG-3', amplifying a fragment of $440 \mathrm{bp}$ from mRNA and $652 \mathrm{bp}$ for genomic DNA. To ensure accuracy of the PCR, samples were run without template (control). Finally, the reactions were electrophoresed on $1.5 \%$ agarose gels and stained with ethidium bromide. The gels were exposed to UV with a white/UV ultraviolet transiluminator (UVP Laboratory Products) and the images quantified using the Scion Images NIH software.

To evaluate levels of $\mathrm{GABA}_{\mathrm{B} 1}$ mRNA expression in pituitaries from different treatment groups, PCRs were performed using the expression of $\beta$-actin mRNA as control of the variation in the RNA concentration in RT reaction. To validate the assay for $\mathrm{GABA}_{\mathrm{B} 1}$ measurements, different amounts of total RNA were reverse transcribed, and aliquots were amplified with the specific primers for $\mathrm{GABA}_{\mathrm{B} 1}$ or $\beta$-actin mRNA for different number of cycles. A linear relationship between the $\mu \mathrm{g}$ of RNA and PCR products was obtained (fig. 1a). As a result, $0.5 \mu \mathrm{g}$ total RNA was used in RT reactions. A linear relationship between the PCR products and cycle number was also obtained when $0.5 \mu \mathrm{g}$ total RNA was used in RT (fig. 1b). As a result, 36 and 20 amplification cycles were selected for $\mathrm{GABA}_{\mathrm{B} 1}$ and $\beta$-actin, respectively. Finally, a linear relationship in detection was also attained when different amounts of cDNA, obtained from $0.5 \mu \mathrm{g}$ reverse-transcribed RNA, were subjected to PCR (fig. 1c).

\section{Statistical Analysis}

Differences in $\mathrm{GABA}_{\mathrm{B}} \mathrm{R}$ subunit expression, $\mathrm{GABA}_{\mathrm{B} 1}$ mRNA levels, neurotransmitters levels, hormonal levels and puberty parameters were analyzed by either one-way or two-way analysis of variance (ANOVA) followed by Tukey HSD for unequal $\mathrm{N}$ test (Statistica $v 5$ ). Data were transformed when the test for homogeneity of variances so required. In the case of LH measurements in 8-day-old animals, no transformation of data allowed compliance to the homogeneity of variances tests, therefore data were analyzed by KruskalWallis non-parametric ANOVA test. Correlations were analyzed with Statistica v 5. In all cases, results were considered significant when $\mathrm{p}<0.05$. 


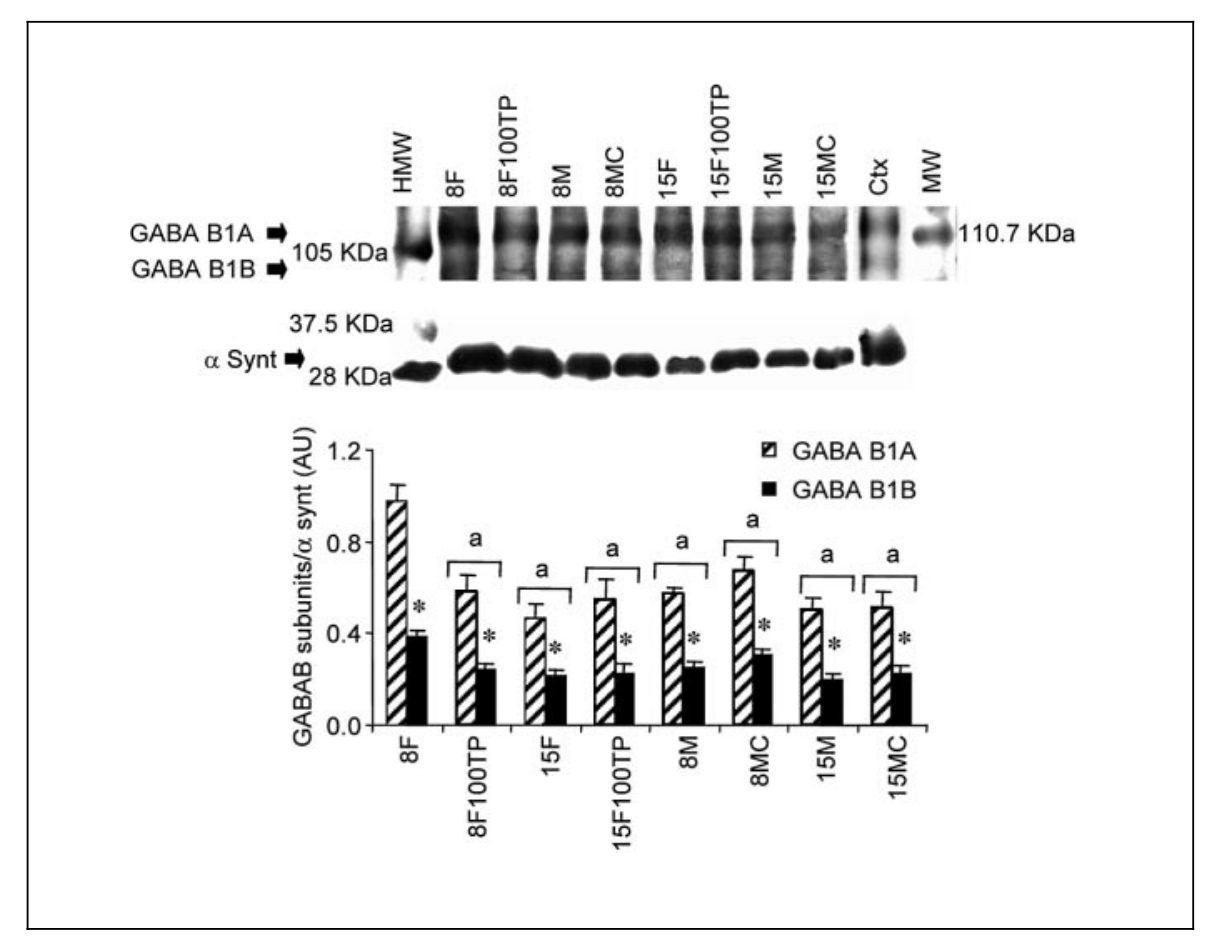

Fig. 2. $G A B A_{B 1}$ receptor subunit expression in anterior hypophysis from 8- and 15-day-old animals under different treatments determined by Western blot with specific antisera. For this and the following figures: $8 \mathrm{~F}$ and 15F: 8- and 15-day-old control females (injected with castor oil), 8F100TP and 15F100TP: 8- and 15-day-old females treated with $100 \mu \mathrm{g}$ of TP on the day of birth, $8 \mathrm{M}$ and $15 \mathrm{M}$ : sham castrated control males and 8MC and 15MC: 8- and 15-day-old males castrated on the day of birth. Upper panel: Representative Western blot for $\mathrm{GABA}_{\mathrm{B} 1 \mathrm{a}}$ and $\mathrm{GABA}_{\mathrm{B} 1 \mathrm{~b}}$ subunit and $\alpha$-syntaxin expression. $\mathrm{Ctx}=$ Cortex membranes used as positive controls;
MW = molecular weight markers. Lower panel: Data are expressed as the ratio of each $\mathrm{GABA}_{\mathrm{B} 1}$ subunit expression to $\alpha$-syntaxin expression. Number of samples per group: $8 \mathrm{~F}=10,8 \mathrm{~F} 100 \mathrm{TP}=7,15 \mathrm{~F}=6$, $15 \mathrm{~F} 100 \mathrm{TP}=5,8 \mathrm{M}=11,8 \mathrm{MC}=11,15 \mathrm{M}=5,15 \mathrm{MC}=5$. Results were analyzed by two-way ANOVA: interaction: n.s., indicating that both subunits follow the same expression pattern among groups; factor subunit: $\mathrm{p}<0.001$, indicating that $\mathrm{GABA}_{\mathrm{B} 1 \mathrm{a}}$ levels are higher than $\mathrm{GABA}_{\mathrm{B} 1 \mathrm{~b}}$ levels; factor treatment: $\mathrm{p}<0.02$ or less; $\mathrm{a}=$ different from control females $(8 \mathrm{~F}) ;{ }^{*}=$ different from $\mathrm{GABA}_{\mathrm{B} 1 \mathrm{a}}$ levels.

\section{Results}

Effects of Neonatal Female Androgenization and Male Castration on $G A B A_{B 1}$ Expression and Hormone

\section{Levels}

In agreement with our previous results, both $\mathrm{GABA}_{\mathrm{B} 1} \mathrm{R}$ subunit proteins, $\mathrm{GABA}_{\mathrm{B}(1 \mathrm{a})}$ and $\mathrm{GABA}_{\mathrm{B}(1 \mathrm{~b}) \text {, }}$ were expressed in male and female anterior pituitary glands from 8- and 15-day-old animals (fig. 2), the former being significantly more abundant in all groups and both splice variants following parallel patterns of expression among treatment groups. Besides, the expression of $\mathrm{GABA}_{\mathrm{B}(1)}$ subunits was maximal in pituitary membranes from 8-day-old females $(8 \mathrm{~F})$, confirming that their expression decreases with age and that it is higher in females than in males $(8 \mathrm{M})$ at early stages of development. No differences between sexes were observed in animals at 15 days of age $(15 \mathrm{~F}$ and $15 \mathrm{M})$. Neonatal androgenization $(100 \mu \mathrm{g}$ TP: 8F100TP) significantly decreased the $\mathrm{GABA}_{\mathrm{B}(1)}$ subunit expression in 8-day-old female rat pituitary membranes reaching levels similar to those observed in control males. On the other hand, neonatal male castration $(8 \mathrm{MC})$ did not significantly alter $\mathrm{GABA}_{\mathrm{B}(1)}$ expression. To determine if these treatments also affected the expression of the $\mathrm{GABA}_{\mathrm{B} 1}$ subunit mRNA, semiquantitative RT-PCR were carried out from pituitaries belonging to the same groups, obtaining similar results (fig. 3).

The neonatal treatments produced alterations in gonadotropin titers, which confirmed their efficacy. Neonatal testosterone treatment in females reduced serum $\mathrm{LH}$ (fig. 4) either to control 8-day-old male levels $(\mathrm{LH}(\mathrm{ng} / \mathrm{ml})$ : $8 \mathrm{~F}: 1.13 \pm 0.09$ vs. $8 \mathrm{~F} 100 \mathrm{TP}: 0.48 \pm 0.06$ or $8 \mathrm{M}: 0.55 \pm$ $0.04, \mathrm{p}<0.01)$ or to even lower levels in 15-day-old rats $(\mathrm{LH}(\mathrm{ng} / \mathrm{ml}): 15 \mathrm{~F}: 1.14 \pm 0.16$ vs. $15 \mathrm{~F} 100 \mathrm{TP}: 0.28 \pm$ 


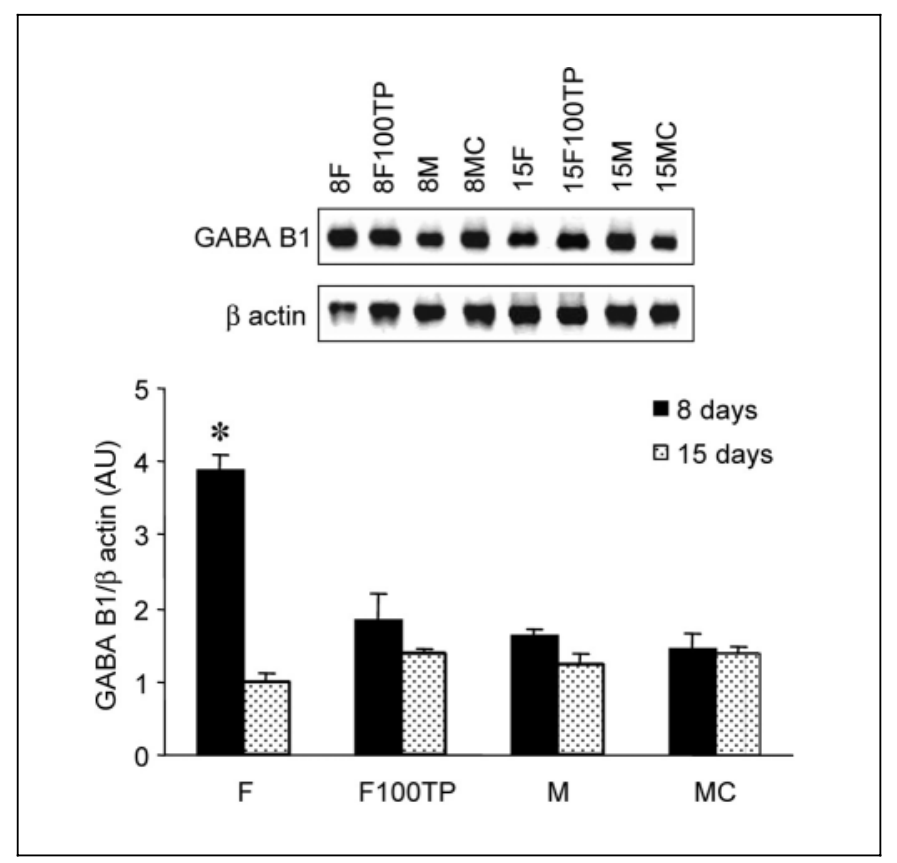

Fig. 3. $G_{A B A} A_{B 1}$ receptor subunit mRNA expression in anterior hypophysis of 8- and 15-day-old animals under different treatments determined by semiquantitative RT-PCR. Upper panel: Representative RT-PCR gel for $\mathrm{GABA}_{\mathrm{B} 1}$ subunit and $\beta$-actin expression. Lower panel: Data are expressed as the ratio of $\mathrm{GABA}_{\mathrm{B} 1}$ subunit expression to $\beta$-actin expression. $\mathrm{AU}=$ Arbitrary units. Results were analyzed by two-way ANOVA taking as factors age and treatments, interaction: $\mathrm{p}<0.001, * \mathrm{p}<0.001$; different from all the other groups. Number of cases per group: $8 \mathrm{~F}=5,8 \mathrm{~F} 100 \mathrm{TP}=5,15 \mathrm{~F}=6,15 \mathrm{~F} 100 \mathrm{TP}=5$, $8 \mathrm{M}=4,8 \mathrm{MC}=5,15 \mathrm{M}=6,15 \mathrm{MC}=4$.

0.05 vs. $15 \mathrm{M}: 0.52 \pm 0.05, \mathrm{p}<0.01)$. In contrast, neonatally castrated males showed a very significant increase in $\mathrm{LH}$ at both ages $(\mathrm{LH}(\mathrm{ng} / \mathrm{ml}): 8 \mathrm{MC}: 2.70 \pm 0.29$ and 15MC: $17.58 \pm 1.24, \mathrm{p}<0.01)$. LH titers in castrated males were significantly higher than in control females. Moreover, the increase in 15-day-old castrated males was considerably more robust than in 8-day-old castrated males. With regard to FSH serum levels (fig. 4), similar results were obtained.

When analyzing testosterone (fig. 5), male levels were significantly higher than in females, as expected $(\mathrm{T}(\mathrm{pg} /$ $\mathrm{ml}): 8 \mathrm{M}: 402.3 \pm 39.8$ vs. $8 \mathrm{~F}: 267.3 \pm 17.6, \mathrm{p}<0.01)$. No differences between ages within each group were observed. Besides, the neonatally castrated males $(\mathrm{T}(\mathrm{pg} / \mathrm{ml})$ : $8 \mathrm{MC}: 267.7 \pm 21.9)$ presented female testosterone levels, whereas androgenized females $(\mathrm{T}(\mathrm{pg} / \mathrm{ml})$ : 8F100TP: $540.1 \pm 72.2$ ) presented male levels, thus displaying elevated testosterone even 14 days after TP administration.

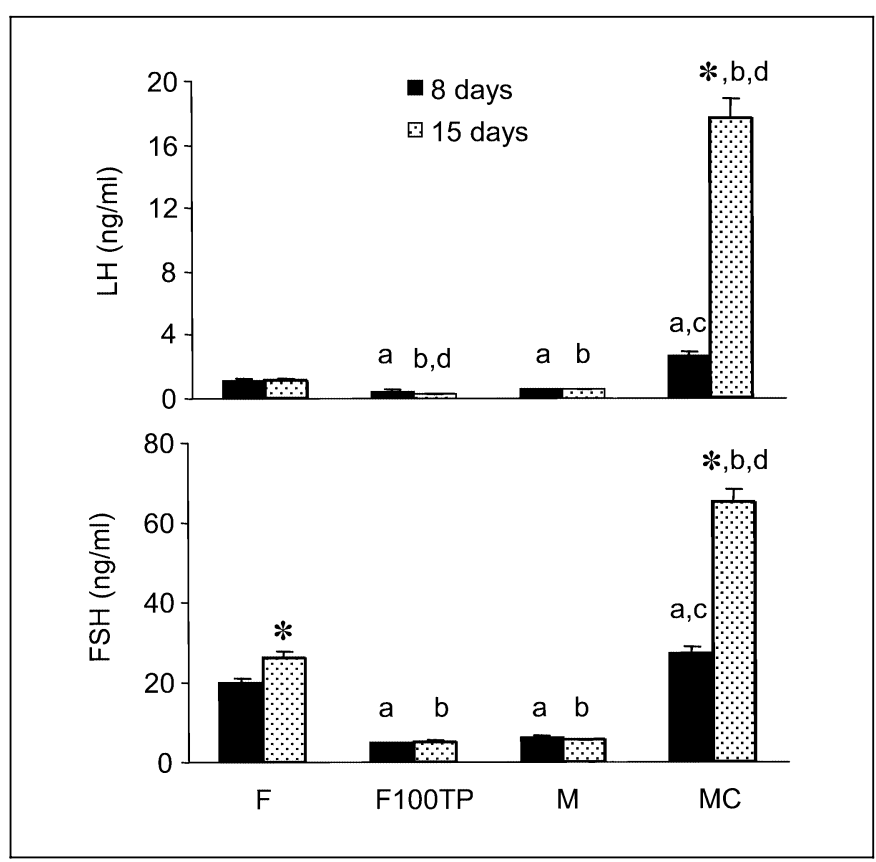

Fig. 4. Gonadotropin serum levels in 8- and 15-day-old animals under different treatments. Upper panel: $\mathrm{LH}(\mathrm{ng} / \mathrm{ml})$; lower panel FSH ( $\mathrm{ng} / \mathrm{ml})$. Data ( $\mathrm{n}=15-20$ animals per group) were analyzed by two-way ANOVA taking as factors age and treatments; interaction: $\mathrm{p}<0.001 ;{ }^{\mathrm{a}}$ different from 8-day-old control females, ${ }^{\mathrm{b}}$ different from 15-day-old control females, ${ }^{c}$ different from 8-day-old control males, d different from 15 -day-old control males, ${ }^{*}$ different from 8 -day-old animals in the same group.

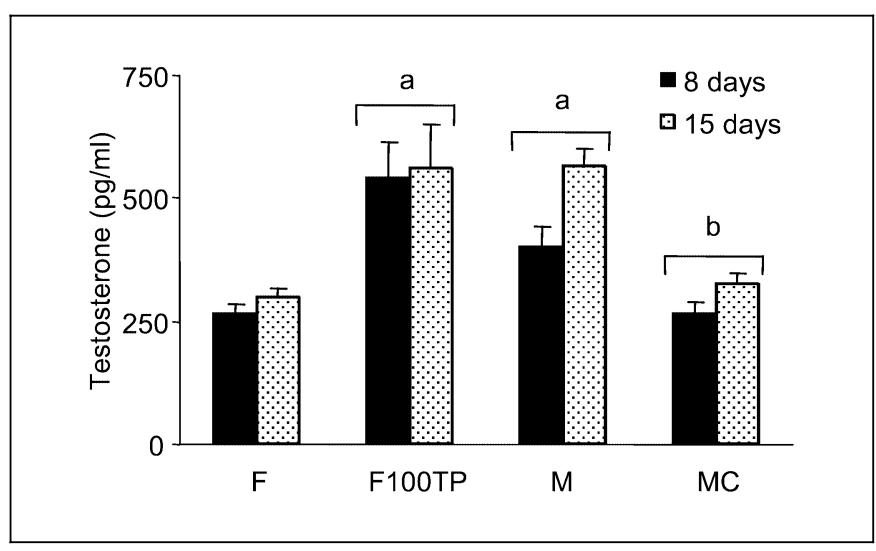

Fig. 5. Testosterone serum levels in 8-and 15-day-old animals under different treatments. Data $(\mathrm{n}=15-20$ animals per group) were analyzed by two-way ANOVA taking as factors age and treatments; interaction: $n$. .s., factor age: $p<0.001$, factor treatments: $p<0.001$ or less; $\mathrm{a}=$ different from control females, $\mathrm{b}=$ different from control males. 


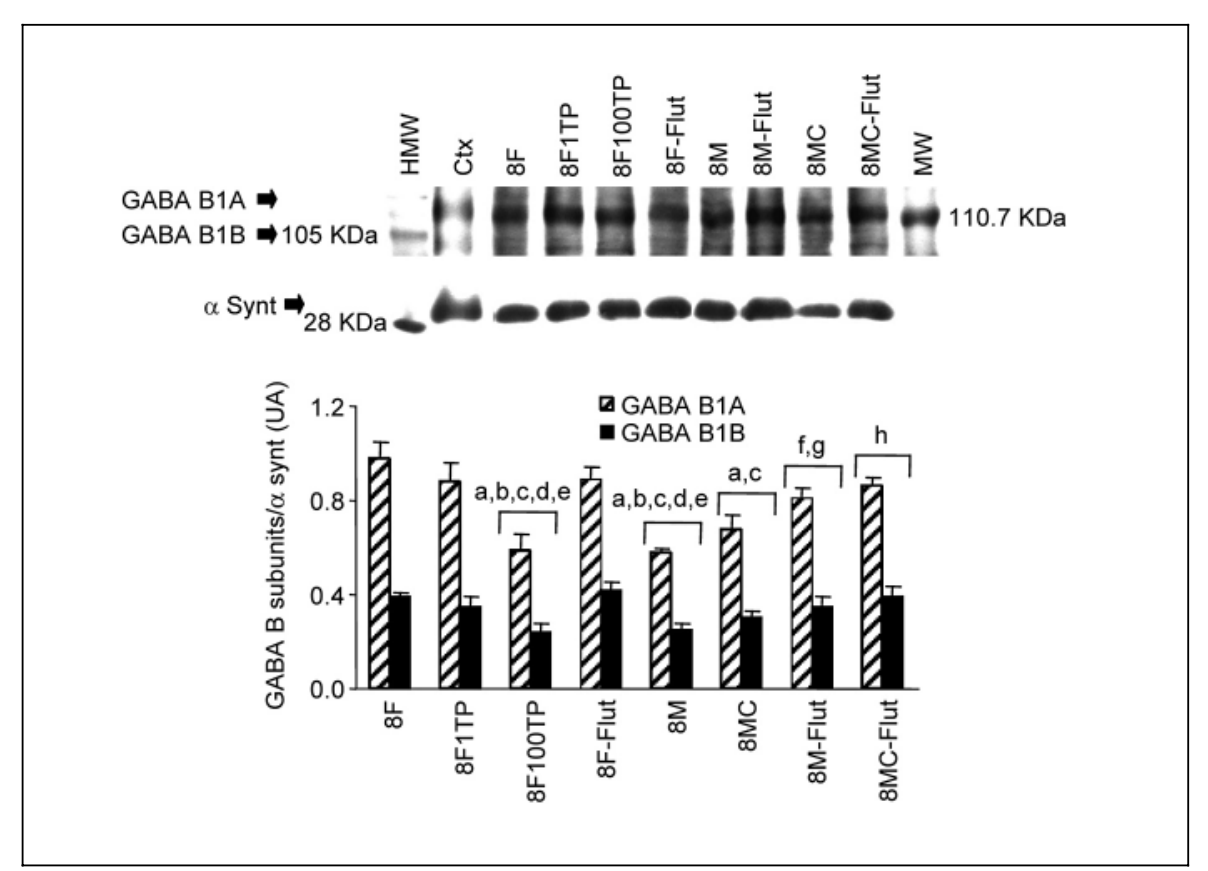

Fig. 6. $\mathrm{GABA}_{\mathrm{B} 1}$ receptor subunit expression in anterior hypophysis from 8-day-old animals under different treatments determined by Western blot with specific antisera. For this and the following figures: 8F: 8-day-old control females, 8F1TP: 8-day-old females injected with $1 \mu \mathrm{g}$ TP on days 1-4 of life, 8F100TP: 8-day-old females treated with $100 \mu \mathrm{g}$ of TP on the day of birth, 8F-Flut: 8-day-old female pups from flutamide-injected mothers, 8M: 8-day-old control males, 8MC: 8-day-old males castrated on the day of birth, 8M-Flut: 8-dayold males from flutamide-injected mothers, 8MC-Flut: 8-day-old males from flutamide-injected mothers and castrated on the day of birth. Upper panel: Representative Western blot for $\mathrm{GABA}_{\mathrm{Bla}}$ and $\mathrm{GABA}_{\mathrm{B} 1 \mathrm{~b}}$ subunit and $\alpha$-syntaxin expression. $\mathrm{Ctx}=\mathrm{Cortex}$ mem- branes used as positive controls; $\mathrm{MW}=$ molecular weight markers. Lower panel: Data are expressed as the ratio of $\mathrm{GABA}_{\mathrm{B} 1}$ subunit expression to $\alpha$-syntaxin expression. Number of samples per group: $8 \mathrm{~F}=12,8 \mathrm{~F} 1 \mathrm{TP}=6: 8 \mathrm{~F} 100 \mathrm{TP}=12,8 \mathrm{~F}-\mathrm{Flut}=6,8 \mathrm{M}=12,8 \mathrm{MC}=12$, $8 \mathrm{M}$-Flut $=6$ and $8 \mathrm{MC}$-Flut $=10$. Results were analyzed by two-way ANOVA: interaction: n.s., indicating that both splice variants follow the same pattern of expression; factor subunit: $p<0.001$, indicating that $\mathrm{GABA}_{\mathrm{B} 1 \mathrm{a}}$ is always more abundant than $\mathrm{GABA}_{\mathrm{B} 1 \mathrm{~b}}$; factor treatment: $\mathrm{p}<0.001$ or less; $\mathrm{a}=$ different from $8 \mathrm{~F}, \mathrm{~b}=$ different from $8 \mathrm{~F} 1 \mathrm{TP}, \mathrm{c}=$ different from $8 \mathrm{~F}-$ Flut, $\mathrm{d}=$ different from $8 \mathrm{M}$-Flut, $\mathrm{e}=$ different from $8 \mathrm{MC}$-Flut, $\mathrm{f}=$ different from $8 \mathrm{~F} 100 \mathrm{TP}, \mathrm{g}=$ different from $8 \mathrm{M}, \mathrm{h}=$ different from $8 \mathrm{MC}$.

\section{Effects of Male in utero Flutamide Treatment and Low-Dose Female Testosterone Administration on Sexual Differentiation of $G A B A_{B}$ Receptor Subunit Expression and Hormone Levels}

As no differences in the expression of $\mathrm{GABA}_{B} \mathrm{R}$ subunits were observed in anterior pituitary membranes of 15-day-old animals, in further experiments only 8-day-old animals were used.

Although treatment of females with $100 \mu \mathrm{g}$ TP on the day of birth induced a decrease in pituitary $\mathrm{GABA}_{\mathrm{B}(1)}$ subunits expression to male levels at 8 days of age, we could not discriminate between an organizational or activational effect of the steroid since testosterone serum levels were still high at sacrifice. On the other hand, the fact that no increase in $\mathrm{GABA}_{\mathrm{B}}$ subunits expression was observed in 8-day-old neonatally castrated males may have been due to incomplete central nervous system defeminization as the result of intrauterine testosterone imprinting on day 18 of gestation.

Therefore, in order to distinguish between a masculinizing effect and a hormonal effect of testosterone, newborn females were treated with a much lower dose androgenization protocol $(1 \mu \mathrm{g}$ TP s.c. during 4 consecutive days, starting on the day of birth). Furthermore, to suppress intrauterine testosterone imprinting, timed pregnant rats were injected with Flut from day 17 of gestation until the day before of delivery.

Again in these experimental groups both splice variants of the $\mathrm{GABA}_{\mathrm{B} 1} \mathrm{R}$ were expressed in a parallel way in all treatment groups, being $\mathrm{GABA}_{\mathrm{B} 1 \mathrm{a}}$ always more abundant than $\mathrm{GABA}_{\mathrm{B} 1 \mathrm{~b}}$. The new, low-dose androgenization protocol did not modify the $\mathrm{GABA}_{\mathrm{B} 1} \mathrm{R}$ subunit protein expression, their levels being similar to 8-day-old females and significantly higher than 8 -day-old males $(\mathrm{p}<0.05)$, 


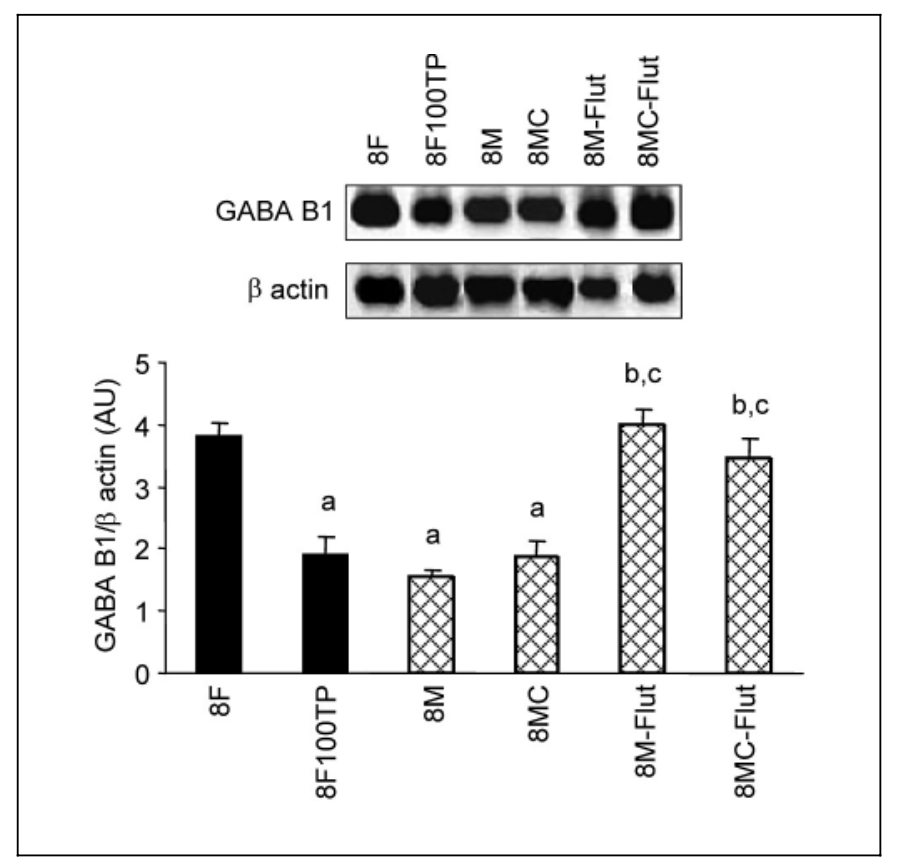

Fig. 7. $G_{A B A} A_{B 1}$ receptor subunit mRNA expression in anterior hypophysis of 8-day-old animals under different treatments determined by semiquantitative RT-PCR. Upper panel: Representative RT-PCR gel for $\mathrm{GABA}_{\mathrm{B} 1}$ subunit and $\beta$-actin expression. Lower panel: Data are expressed as the ratio of $\mathrm{GABA}_{\mathrm{B} 1}$ subunit expression to $\beta$-actin expression. Results were analyzed by one-way ANOVA. $\mathrm{p}<0.001 ; \mathrm{a}=$ different from $8 \mathrm{~F}, \mathrm{~b}=$ different from $8 \mathrm{M}, \mathrm{c}=$ different from $8 \mathrm{MC}$. Number of cases per group: $8 \mathrm{~F}=5,8 \mathrm{~F} 100 \mathrm{TP}=5,8 \mathrm{M}=$ $4,8 \mathrm{MC}=5,8 \mathrm{M}$-Flut $=4$ and $8 \mathrm{MC}$-Flut $=4$.

while the higher dose continued to be effective (8F100TP) (fig. 6). In 8-day-old male pituitary membranes from animals exposed in utero to Flut, a significant increase in $\mathrm{GABA}_{\mathrm{B}(1)}$ subunit levels could be observed (8M-Flut vs. $8 \mathrm{M}, \mathrm{p}<0.05)$. In addition, males, in which testosterone had not exerted its action during both periods of sexual differentiation (8MC-Flut), displayed higher $\mathrm{GABA}_{\mathrm{B}(1)}$ subunits expression than $8 \mathrm{M}$ and also statistically higher than $8 \mathrm{MC}$ (8MC-Flut vs. $8 \mathrm{MC}, \mathrm{p}<0.05)$. On the other hand, prenatal Flut treatment did not alter $\mathrm{GABA}_{\mathrm{B}} \mathrm{R}$ subunits expression in 8-day-old females (fig. 6). RT-PCR confirmed these results at mRNA level (fig. 7).

To corroborate the effectiveness of the treatments gonadotropin serum levels in the different animal groups were analyzed. Gentle androgenization $(8 \mathrm{~F} 1 \mathrm{TP})$ did not induce any alteration in either FSH or LH titers at the time of sacrifice (fig. 8) $(\mathrm{LH}(\mathrm{ng} / \mathrm{ml}): 8 \mathrm{~F}: 2.00 \pm 0.18 \mathrm{vs}$. 8F1TP: $2.59 \pm 0.24$, n.s.). Males prenatally exposed to Flut showed an intermediate level, between control male

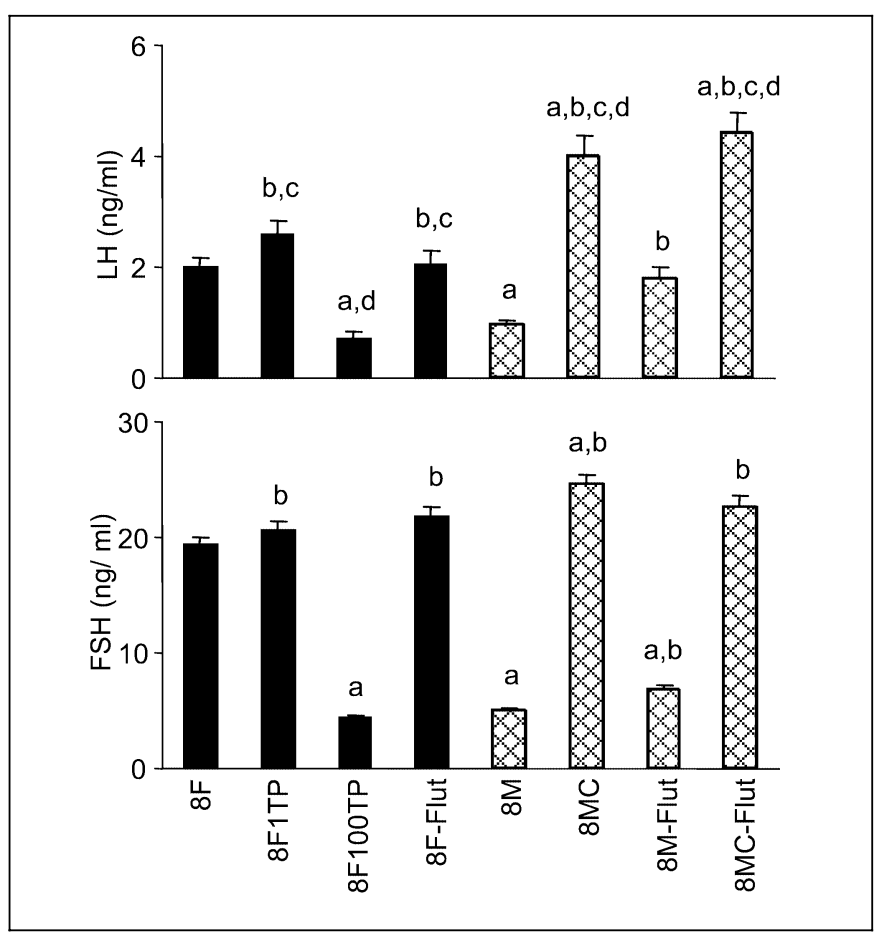

Fig. 8. Gonadotropin serum levels in 8-day-old animals under different treatments. Upper panel: LH (ng/ml), lower panel FSH (ng/ml). For LH data were analyzed by a non-parametric ANOVA test, $\mathrm{p}<$ $0.001 ; \mathrm{a}=$ different from $8 \mathrm{~F}, \mathrm{~b}=$ different from $8 \mathrm{~F} 100 \mathrm{TP}, \mathrm{c}=$ different from $8 \mathrm{M}, \mathrm{d}=$ different from $8 \mathrm{M}$-Flut. For FSH, data were analyzed by one-way ANOVA, $\mathrm{p}<0.001$; $\mathrm{a}=$ different from $8 \mathrm{~F}, \mathrm{~b}=$ different from 8 M. $n=15-20$ animals per group.

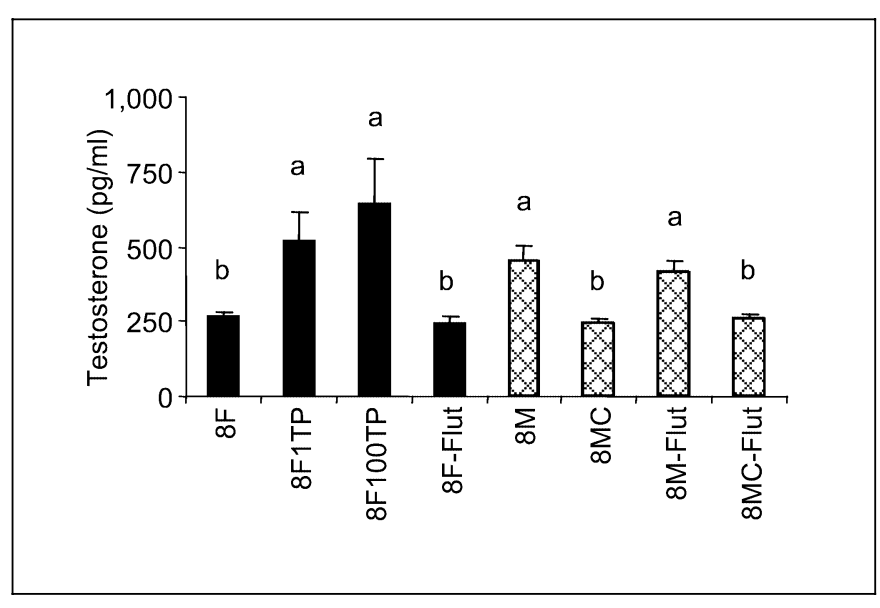

Fig. 9. Testosterone serum levels in 8-day-old animals under different treatments. Data $(n=15-20$ animals per group) were analyzed by one-way ANOVA, $\mathrm{p}<0.001 ; \mathrm{a}=$ different from $8 \mathrm{~F}, \mathrm{~b}=$ different from $8 \mathrm{M}$. 
Fig. 10. Glutamate, GABA, aspartate and taurine levels ( $\mu \mathrm{mol} / \mathrm{g}$ of tissue) in brain cortex form 8-day-old animals under different treatments; $\mathrm{n}=6-11$ animals per group. Data were analyzed by one-way ANOVA, being nonsignificant for the 4 neurotransmitters analyzed.

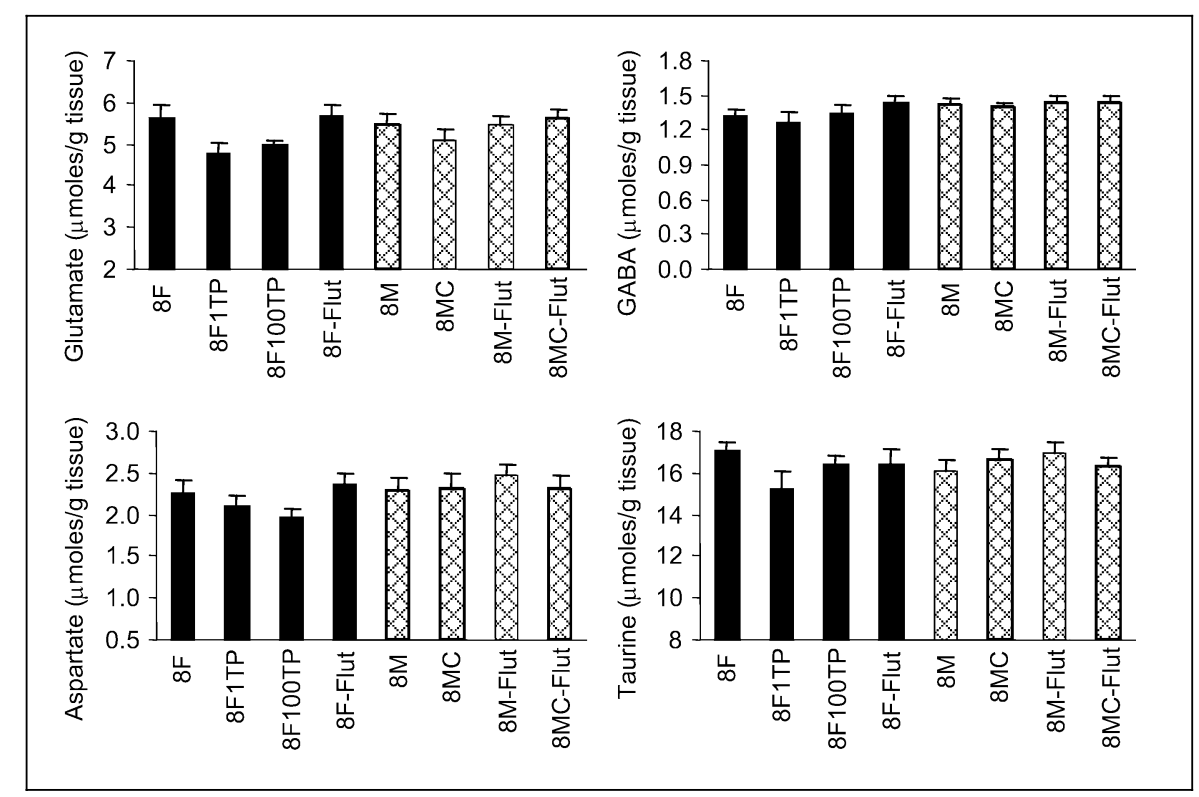

and female values, for both gonadotropins ( $\mathrm{LH}(\mathrm{ng} / \mathrm{ml})$ : 8M: $0.97 \pm 0.08$ vs. $8 \mathrm{M}$-Flut: $1.81 \pm 0.21$, n.s.). Fluttreated neonatally castrated males presented similar gonadotropin patterns to castrated males ( $\mathrm{LH}(\mathrm{ng} / \mathrm{ml})$ : 8MC-Flut: $4.44 \pm 0.35$ vs. $8 \mathrm{MC}: 4.01 \pm 0.35$, n.s.). Flut treatment did not modify serum gonadotropins in control females.

Serum testosterone in females submitted to the low dose androgenization protocol (fig. 9), still presented elevated titers of this hormone at 8 days of age, not differing from 8F100TP and 8M (T (pg/ml): 8F1TP: $520.5 \pm 90.9$ vs. 8 F100TP: $647.1 \pm 144.2$ vs. 8 M: $453.1 \pm 48.8$, n.s.). With regard to prenatally Flut-treated animals, $8 \mathrm{M}$-Flut showed control male testosterone levels and 8MC-Flut had titers similar to those of castrated male (8MC) (T (ng/ ml): 8M-Flut: $415.0 \pm 37.8$ vs. 8 MC-Flut: $256.8 \pm 19.7$ vs. $8 \mathrm{MC}: 243.3 \pm 15.6, \mathrm{p}<0.01)$. Flut treatment did not alter this hormone in females.

\section{Effects of Perinatal Sex Hormone Manipulation on \\ Neurotransmitter Levels}

GABA has been shown to modulate the expression of its own receptors in the CNS [47]. Therefore, we evaluated GABA and glutamate (its biosynthetic precursor) in the same 8-day-old groups in the hypothalamus, an area critically involved in the control of pituitary function and in cortex, selected as a control area. In addition, taurine and aspartate were evaluated to determine specificity of effects.

Sexual Differences in Pituitary GABA ${ }_{B}$ Receptors
In cortex, no differences in taurine, aspartate, glutamate or GABA were observed among any experimental groups $(8 \mathrm{~F}, 8 \mathrm{~F} 1 \mathrm{TP}, 8 \mathrm{~F} 100 \mathrm{TP}, 8 \mathrm{~F}-\mathrm{Flut}, 8 \mathrm{M}, 8 \mathrm{MC}, 8 \mathrm{M}-$ Flut and 8MC-Flut) (fig. 10). In contrast, glutamate levels in the hypothalamus were significantly lower in all male groups, regardless of treatments, than in control females (fig. 11). Surprisingly, Flut-treated females showed low glutamate levels as well ( $\mathrm{p}<0.05$ with respect to control females), similar to male titers. Interestingly, hypothalamic GABA levels in the different groups showed the same pattern as pituitary $\mathrm{GABA}_{\mathrm{B}} \mathrm{R}$ expression (fig. 11). Control female GABA levels were higher than control male levels and $100 \mu \mathrm{g}$ TP in females, but not $1 \mu \mathrm{g} \mathrm{TP}$, decreased them to control male levels. In addition, Flut plus castration increased male GABA to control female levels. A possible relationship between hypothalamic GABA levels and pituitary $\mathrm{GABA}_{B} \mathrm{R}$ expression is suggested by our results. In contrast, taurine and aspartate showed similar levels in the hypothalami of the different groups (fig. 11).

\section{Effect of Androgenization Protocols on the \\ Hypothalamic-Pituitary-Ovarian Axis}

With the purpose of corroborating the effects of the different testosterone treatments on sexual differentiation, a group of female rats of each group was allowed to reach adulthood, studying different parameters along their development (table 1).

First, the day of vaginal opening was registered. In females that had been injected with $1 \mu \mathrm{g}$ TP for 4 consecu-

Neuroendocrinology 2004;80:129-142 
Fig. 11. Glutamate, GABA, aspartate and taurine levels ( $\mu \mathrm{mol} / \mathrm{g}$ of tissue) in hypothalami from 8-day-old animals under different treatments; $n=6-11$ animals per group. Data were analyzed by one-way ANOVA: $\mathrm{p}<0.01$ for glutamate and GABA. ${ }^{\mathrm{a}} \mathrm{p}<0.05$ or less vs. $8 \mathrm{~F} ;{ }^{\mathrm{b}} \mathrm{p}<0.05$ vs. $8 \mathrm{M}$.

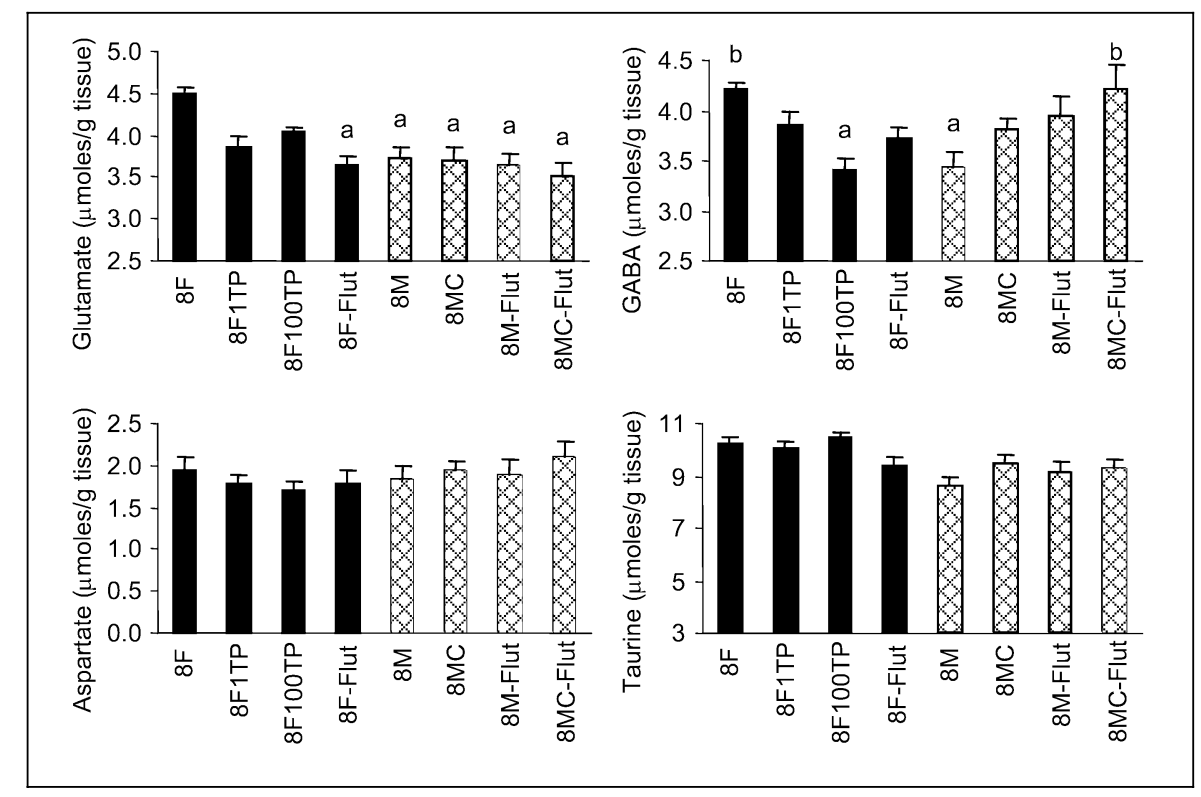

Table 1. Puberty and cyclicity parameters in control and testosterone-treated adult female rats

\begin{tabular}{|c|c|c|c|c|c|c|c|c|}
\hline \multirow{2}{*}{$\begin{array}{l}\text { Adult } \\
\text { females }\end{array}$} & \multirow{2}{*}{$\begin{array}{l}\text { Day } \\
\text { of VO }\end{array}$} & \multirow{2}{*}{$\begin{array}{l}\text { BW at VO } \\
\mathrm{g}\end{array}$} & \multirow{2}{*}{$\begin{array}{l}\text { BW on } \\
\text { day } 34\end{array}$} & \multirow{2}{*}{$\begin{array}{l}\text { Estrous cycles } \\
\text { at adulthood }\end{array}$} & \multicolumn{2}{|c|}{$\mathrm{LH}, \mathrm{ng} / \mathrm{ml}$} & \multicolumn{2}{|c|}{$\mathrm{FSH}, \mathrm{ng} / \mathrm{ml}$} \\
\hline & & & & & $\mathrm{AM}$ & PM & $\mathrm{AM}$ & PM \\
\hline Control & $38 \pm 1$ & $112.6 \pm 3.7$ & $94.4 \pm 1.9$ & $85 \%$ regular & $3.6 \pm 0.6$ & $23.4 \pm 10.6^{a}$ & $4.7 \pm 0.5$ & $8.0 \pm 1.5^{b}$ \\
\hline $1 T P$ & $34 \pm 1^{*}$ & $92.1 \pm 3.5^{*}$ & $92.1 \pm 3.5$ & $100 \%$ anestrus & $6.1 \pm 1.2$ & $7.7 \pm 1.0$ & $8.9 \pm 1.6$ & $15.5 \pm 2.8$ \\
\hline $100 \mathrm{TP}$ & NO & - & $98.0 \pm 3.0$ & - & $4.8 \pm 0.7$ & $5.2 \pm 1.0$ & $10.9 \pm 1.1$ & $12.7 \pm 2.7$ \\
\hline
\end{tabular}

Adult female rats, belonging to the second experimental design (Materials and Methods) evaluated at the end of puberty and in adulthood. $\mathrm{VO}=$ Vaginal opening; $\mathrm{BW}=$ body weight; adult females $1 \mathrm{TP}=\mathrm{VO}$ as pinhole.

$* \mathrm{p}<0.05$, different from controls.

${ }^{a}$ Different from AM levels; ${ }^{b}$ FSH (AM and PM) levels different from 1TP and 100TP.

tive days (F1TP), vaginal opening occurred on $34 \pm 1$ days of age, significantly earlier than in control females $(\mathrm{p}<0.05)$. This difference was not due to a difference in body weight at this age. In contrast, females that received a single injection of $100 \mu \mathrm{g} \mathrm{TP}$ on the day of birth (F100TP) did not display vaginal opening until day 75 of age (when the experiment ended). Second, estrous cycles were followed after vaginal opening. While the $85 \%$ of control females (F) showed regular cycles, none of the F1TP females cycled (100\% anestrous).

Finally, serum gonadotropins in these animals were analyzed. As expected, control females presented a significant increase in LH levels in the proestrous afternoon while no differences in either F1TP or F100TP LH titers between morning and afternoon were observed. With regard to serum FSH, F1TP and F100TP had significant higher levels than control females $(p<0.02)$ at adulthood.

\section{Discussion}

We have previously described a clear sexually dimorphic expression pattern for adenohypophyseal $\mathrm{GABA}_{\mathrm{B}} \mathrm{Rs}$ at early stages of development. $\mathrm{GABA}_{\mathrm{B}(1)}$ subunit decreases with age in both sexes, being significantly higher in females than in males at 4 and 12 days of age [28]. In rats there is a sensitive developmental period during which sexual differentiation of neural substrates proceeds 
irreversibly under the influence of gonadal hormones. This period starts a few days before birth and ends approximately 10 days thereafter [48]. Perinatal alterations in the endogenous gonadal hormone levels induce changes in sexually dimorphic physiologic, neuroanatomic, molecular and behavioral characteristics, independently of the genetic sex of the animals [38, 48-50]. Similar data were obtained after neonatal exposure to stress [51].

In consequence, we evaluated $\mathrm{GABA}_{\mathrm{B}} \mathrm{R}$ subunit expression in neonatally androgenized female and castrated male pituitaries at 8 and 15 days of age in comparison to controls. In agreement with our previous results [28], expression levels were higher in 8-day-old than 15-day-old females or 8-day-old males. At 15 days of age, no sexual differences in $\mathrm{GABA}_{\mathrm{B}} \mathrm{Rs}$ were evident. Sexual differences may be manifested after the critical period of hormonal action has elapsed and high steroid levels are no longer present $[52,53]$, as in sexual differences in gonadotropin secretion [30]. In contrast, many characteristics cannot be differentiated by sex in adulthood because these sex differences are present only transiently during development [32, 54]. For example, around birth, male rats express much higher levels of progesterone receptor in the medial preoptic area than do females; this sex difference starts to disappear once the ovaries become active [55]. GABA $\mathrm{B}_{\mathrm{B}} \mathrm{R}$ gene expression exhibits similar characteristics.

Neonatal female androgenization reduced $\mathrm{GABA}_{\mathrm{B}} \mathrm{R}$ expression to male levels, while neonatal male castration did not induce significant effects. To corroborate the effectiveness of treatments, gonadotropins and testosterone were measured, since both parameters are sexually dimorphic [56]. Indeed, gonadotropins are higher in females than in males at 8 and 15 postnatal days, FSH also being higher in 15-day-old than in 8-day-old females [30, 56]. Females treated neonatally with $100 \mu \mathrm{g}$ TP showed male gonadotropin patterns, while neonatally castrated males showed increased gonadotropin secretion, even higher than control females. This may be due to the lack of negative feedback action of circulating steroids after castration. Moreover, in 15-day-old orchidectomized males, levels were significantly higher than in 8-day-old castrated males. It has been demonstrated that hypothalamic GnRH increases along development attaining adult levels in males at 30 days of age [57]. In addition, days 12-18 of postnatal development are characterized in females by high FSH, sporadic spikes of LH and a high sensitivity to GnRH $[30,56,58]$. In contrast, $\mathrm{LH}$ and FSH, as well as pituitary GnRH sensitivity, are low in males at this age [59]. Therefore, high gonadotropins in 15-day-old castrated males may be the consequence of a combination of acquired female characteristics plus an increased GnRH secretion due to castration. Thus, these hormonal changes indicate effectiveness of treatments. In addition, these results suggest that while neonatal castration is successful in demasculinizing and feminizing the control of gonadotropin secretion, it is insufficient to modify $\mathrm{GABA}_{\mathrm{B}} \mathrm{R}$ expression. It is interesting to note that neonatally castrated males showed measurable levels of testosterone, probably of adrenal origin $[60,61]$, in agreement with previous reports [62]. Furthermore, $100 \mu \mathrm{g}$ TPtreated females were effectively masculinized in their gonadotropin secretion patterns and testosterone levels as well as $\mathrm{GABA}_{\mathrm{B}} \mathrm{R}$ expression.

While these experiments conveyed the idea that $\mathrm{GABA}_{\mathrm{B}} \mathrm{R}$ expression is under steroid hormone control at early stages of development, some uncertainties emerged from our results. Was castration insufficient to modify $\mathrm{GABA}_{\mathrm{B}} \mathrm{R}$ expression in males because intrauterine testosterone imprinting had already occurred in these animals? Was the testosterone effect in females due to neonatal masculinization of $\mathrm{GABA}_{\mathrm{B}} \mathrm{R}$ expression or to high circulating androgens, still present at the time of sampling?

To answer these questions a new set of experiments was designed in 8-day-old animals.

In addition to neonatal castration, in a group of males the effect of intrauterine testosterone (first androgenizing peak) was abolished by treatment of pregnant rats with Flut, a non-steroidal anti-androgen which blocks $\mathrm{T}$ and DHT action [29, 49, 63]. Moreover, a third group of males was exposed to embryonic Flut treatment and castrated at birth to abolish both masculinizing peaks. With regards to females, in addition to the $100 \mu \mathrm{g}$ TP androgenization protocol, a second low-dose androgenization scheme was undertaken [42].

Males treated with Flut showed a significant increase in $\mathrm{GABA}_{\mathrm{B}(1)}$ expression when compared to controls. In neonatally castrated Flut-treated males, GABA $_{B} R$ subunit expression was even higher. The anti-androgen also blocked masculinization of various androgen-dependent anatomical characteristics (e.g. external genitalia). Flut did not modify gonadotropins or $\mathrm{GABA}_{\mathrm{B}} \mathrm{R}$ expression in females, as was to be expected. These results clearly demonstrate that testosterone and/or its metabolites [64, 65] play crucial roles in determining pituitary $\mathrm{GABA}_{\mathrm{B}} \mathrm{R}$ subunit expression at early stages of development, both androgenizing peaks being involved, though the intrauterine one appears to be the most critical. The fact that Flut completely reverted the male $\mathrm{GABA}_{\mathrm{B}} \mathrm{R}$ expression pattern to a female pattern suggests that the androgen receptor is selectively important in the sexual differentiation of 
the pituitary, at least regarding the parameter analyzed here. This hypothesis is supported by the results obtained by neonatal testosterone treatment in females.

On the other hand, females treated with the low dose androgenization protocol showed no alterations in $\mathrm{GABA}_{\mathrm{B}} \mathrm{R}$ expression or in gonadotropins. Testosterone was high in these animals, similar to control males and to 100- $\mu \mathrm{g}$ TP-treated females, suggesting that the effect observed in $\mathrm{GABA}_{B} \mathrm{R}$ expression in the $100-\mu \mathrm{g}$ TP group was not due to testosterone presence at the time of sampling. Though this low dose androgenizing protocol did not modify $\mathrm{GABA}_{\mathrm{B}} \mathrm{R}$ expression, it profoundly altered the hypothalamic-pituitary-ovarian axis; these animals presented early vaginal opening in an atypical way (pinhole, as reported previously [42]), elevated FSH and lack of cycling or gonadotropin surges in adulthood. In addition, alterations in uterine horns and ovarian volume were also observed at autopsy.

Results from the androgenization protocols suggest that while both were effective in altering gonadotropin secretion in adulthood, a certain dose of testosterone is needed to masculinize $\mathrm{GABA}_{\mathrm{B}} \mathrm{R}$ expression. It has been proposed that different structures, tissues, characteristics may display differential susceptibility to androgen action, requiring different doses for effects to be observed [42, 66, 67]. Interestingly, sex steroid modulation of $\mathrm{GABA}_{B} \mathrm{R}$ expression in several CNS areas has also been suggested in cycling rats [68].

The evidence of steroid-dependent sexual differences in $\mathrm{GABA}_{\mathrm{B}} \mathrm{R}$ expression is not an isolated observation, since the participation of GABA and its receptors has been proposed to play key roles in sexual differentiation of the brain and in sexually dimorphic hormone secretion patterns [69-72].
As GABA had been shown to modulate the expression of its own receptors in the CNS [47], we evaluated GABA and other neurotransmitters in the hypothalami of 8-dayold animals in the different treatment groups. Interestingly, only hypothalamic GABA levels showed the same pattern as pituitary $\mathrm{GABA}_{\mathrm{B}} \mathrm{R}$ expression, this neurotransmitter being higher in females than in males, and modulated by steroid manipulation in the same way. Though in general testosterone was proposed to increase GABA levels $[68,72]$, in some areas as the amygdala and the medial septal nucleus castration was shown to induce an increase in this neurotransmitter [73], similar to our data. Our present in vivo results cannot discriminate whether androgen action on pituitary $\mathrm{GABA}_{\mathrm{B}} \mathrm{R}$ expression and hypothalamic GABA levels are parallel responses to the same stimulus or one is the consequence of the other. In vitro experiments have already been undertaken to discriminate between these possibilities.

In conclusion, these data demonstrate that testosterone plays a role in modulating sexually dimorphic pituitary $\mathrm{GABA}_{\mathrm{B}} \mathrm{R}$ expression and hypothalamic GABA levels at early stages of development. Prenatal exposure of males to androgens determines postnatal pituitary $\mathrm{GABA}_{\mathrm{B} 1} \mathrm{R}$ expression, while increased neonatal TP can decrease $\mathrm{GABA}_{\mathrm{B} 1} \mathrm{R}$ expression levels normally found in females.

\section{Acknowledgments}

Grants: This work was supported by by Agencia Nacional de Promoción Científica y Tecnológica (ANPCYT, BID 1201/OC AR PICT 2000, 0508664 to C.L.); Consejo Nacional de Investigaciones Científicas y Técnicas (PIP 02231 to V.A.R.L.-L. and PIP 02282 to C.L); Universidad de Buenos Aires (M045 to C.L.); Ministerio de Salud de la Nación (to V.A.R.L.-L.).

\section{References}

$\checkmark 1$ Libertun C, Arakelian MC, Larrea GA, Foglia VC: Inhibition of prolactin secretion by GABA in female and male rats. Proc Soc Exp Biol Med 1979:161:28-31.

-2 Fiszer de Plazas S, Becu D, Mitridate de Novara A, Libertun C: GABA receptors in anterior pituitary and brain areas after median eminence lesions. Endocrinology 1982;111:19741978.

-3 Vincent SR, Hokfelt T, Wu JY: GABA neuron systems in hypothalamus and the pituitary gland. Neuroendocrinology 1982;34:117-125.

4 Gamel-Didelon K, Corsi C, Pepeu G, Jung H, Gratzl M, Mayerhofer A: An autocrine role for pituitary GABA: Activation of GABA-B receptors and regulation of growth hormone levels. Neuroendocrinology 2002;76:170-177.
5 Kaupmann K, Malitschek B, Schuler B, Heid J, Froestl W, Beck P, Mosbacher J, Bischoff S, Kulik A, Shigemoto R, Karschin A, Bettler B: GABA B receptor subtypes assemble into functional heteromeric complexes. Nature 1998; 396:683-687.

66 White J, Wise A, Main M, Green A, Fraser N, Disney G, Barnes A, Emson P, Foord S, Marshall $\mathrm{F}$ : Heterodimerization is required for the formation of a functional GABAB receptor. Nature 1998;396:679-682.

7 Bowery NG, Bettler B, Froestl W, Gallagher JP, Raiteri M, Bonner TI, Enna SJ: International Union of Pharmacology. XXXIII. Mammalian g-aminobutyric acid B receptors: Structure and function. Pharmacol Rev 2002;54: 247-264.

\footnotetext{
8 Kaupmann K, Huggel K, Heid J, Flor P, Bischoff S, Mickel S, McMaster G, Angst C, Bittiger H, Froestl W, Bettler B: Expression cloning of GABA B receptors uncovers similarity to metabotropic glutamate receptors. Nature 1997;386:239-246.

-9 Isomoto S, Kibara M, Sakurai-Yamashita Y, Nagyama Y, Uezono Y, Yano K, Taniyama K: Cloning and tissue distribution of novel splice variants of the rat GABAB receptor. Biochem Biophys Res Commun 1998;253:10-15.

10 Pfaff T, Malitschek B, Kaupmann K, Prézeau L, Pin J-P, Bettler B, Karschin A: Alternative splicing generates a novel isoform of the rat metabotropic GABABR1 receptor. Eur J Neurosci 1999; 11:2874-282.
}

$\overline{140} \quad \overline{\text { Neuroendocrinology 2004;80:129-142 }}$

Bianchi/Catalano/Bonaventura/Silveyra/ Bettler/Libertun/Lux-Lantos 
11 Schwatz DA, Barry G, Eliasof SD, Petroski RE, Conlon PJ, Maki RA: Characterization of g-aminobutyric acid receptor $\operatorname{GABAB}(1 \mathrm{e})$, a GABAB(1) splice variant encoding a truncated receptor. J Biol Chem 2000;275:32174-32181.

$\checkmark 12$ Calver AR, Medhurst AD, Robbins MJ, Charles KJ, Evans ML, Harrison DC, Stammers M, Hughes SA, Hervieu G, Couve A, Moss JL, Middlemiss DN, Pangalos MN: The expression of GABAB1 and GABAB2 receptor subunits in the CNS differs from that in peripheral tissues. Neuroscience 2000;100:155-170.

$\checkmark 13$ Lux-Lantos V, Becu-Villalobos D, Bianchi M, Rey-Roldán EB, Chamson-Reig A, Pignataro $\mathrm{O}$, Libertun $\mathrm{C}$ : GABAB receptors in anterior pituitary cells. Neuroendocrinology 2001;73: 334-343.

14 Lux VAR, Somoza GM, Libertun C: b-(4Chlorophenyl)GABA (baclofen) inhibits prolactin and thyrotropin release by acting on the rat brain. Proc Soc Exp Biol Med 1986;183: 358-362.

15 Lux-Lantos VAR, Rey EB, Libertun C: Activation of GABA B receptors in the anterior pituitary inhibits prolactin and luteinizing hormone secretion. Neuroendocrinology 1992;56: 687-693.

16 Rey-Roldán EB, Lux-Lantos VAR, Gonzalez Iglesias A, Becu-Villalobos D, Libertun C: Baclofen, a gamma-aminobutyric acid $\mathrm{B}$ agonist, modifies hormonal secretion in pituitary cells from infantile female rats. Life Sci 1996;58: 1059-1065.

17 Rey-Roldán EB, Lux-Lantos V, Chamson-Reig A, Libertun C: In vivo interaction of baclofen, TRH and serotonin on PRL and TSH secretion in the developing and adult male and female rats. Life Sci 1997;61:2283-2290.

-18 Mayerhofer A, Höne-Zell B, Gamel-Didelon K, Jung H, Redecker P, Grube D, Urbanski HF, Gasnier B, Fritschy JM, Gratzl M: Gamma-aminobutyric acid (GABA): A para- and/or autocrine hormone in the pituitary. FASEB 2001;15:1089-1091.

19 Simeone TA, Donevan SD, Rho JM: Molecular biology and ontogeny of gamma-aminobutyric acid (GABA) receptors in the mammalian central nervous system. J Child Neurol 2003;18: 39-48.

-20 Jussofie A: Steroid modulation of central nervous GABAA receptor binding in three female rat brain areas during postnatal development. Dev Neurosci 1995; 17:335-342.

-21 Turgeon SM, Albin RL: Postnatal ontogeny of GABAB binding in the rat brain. Neuroscience 1994;62:601-613.

22 Duvilanski BH, Muñoz-Mainez V, Díaz MdC, Seilicovich A, Debeljuk L: Serum prolactin levels and GABA-related enzymes in the hypothalamus and anterior pituitary during maturation in the rat. Neuroendocrinol Lett 1984;4: 243-251.

23 Lacau-Mengido IM, Diaz-Torga GS, Libertun C: Diazepam: Endocrine effects and hypothalamic binding sites in the developing male and female rat. Life Sci 1989;45:567-575.
24 Waagepetersen HS, Sonnewald U, Schousboe A: The GABA Paradox: Multiple roles as metabolite, neurotransmitter, and neurodifferentiative agent. J Neurochem 1999;73:13351342.

25 Bowery NG: Pharmacology of mammalian GABAB receptors; in Enna S, Bowery NG (eds): The GABA Receptors. Totowa, Humana Press, 1996, pp 1-30.

26 Malitschek B, Rüegg D, Heid J, Kaupmann K, Bittiger H, Froestl W, Bettler B, Kuhn R: Developmental changes of agonist affinity at GABABR1 receptor variants in the rat. Mol Cell Neurosci 1998;12:56-64.

27 Fritschy JM, Meskenaite V, Weinmann O, Honer M, Benke D, Mohler H: GABAB-receptor splice variants GB1a and GB1b in rat brain: Developmental regulation, cellular distribution and extrasynaptic localization. Eur J Neurosci 1999;11:761-768.

28 Bianchi MS, Rey-Roldán EB, Bettler B, Ristig D, Malitschek B, Libertun C, Lux-Lantos V: Ontogenic expression of anterior pituitary GABAB receptor subunits. Neuropharmacology 2001;40:185-192.

29 Fitch RH, Denenberg VH: A role for ovarian hormones in sexual differentiation of the brain. Behav Brain Sci 1998;21:311-352.

30 Becu-Villalobos D, Gonzalez Iglesias A, DíazTorga G, Hockl P, Libertun C: Brain sexual differentiation and gonadotropins secretion in the rat. Cell Mol Neurobiol 1997;17:699-715.

31 Arnold A: Gonadal steroid induction of structural sex differences in the central nervous system. Ann Rev Neurosci 1984;7:413-442.

32 Tobet SA, Hanna IK: Ontogeny of sex differences in the mammalian hypothalamus and preoptic area. Cell Mol Neurobiol 1997;17: 565-601.

33 Weisz J, Ward IL: Plasma testosterone and progesterone titers of pregnant rats, their male and female fetuses, and neonatal offspring. Endocrinology 1980;106:306-316.

>34 Jost A, Vigier B, Prepin J, Perchellet JP: Studies on sex differentiation in mammals. Rec Prog Horm Res 1973;29:1-4.

35 Ward IL: Maternal stress alters plasma testosterone in fetal males. Science 1980;207:328329.

36 Perrot-Sinal TS, Davis AM, McCarthy MM: Developmental sex differences in glutamic acid decarboxylase $(\mathrm{GAD}(\& \%))$ and the housekeeping gene, GAPDH. Brain Res 2001;922:201208

37 Carrer HF, Cambiaso MJ: Sexual differentiation of the brain: Genes, estrogens, and neurotrophic factors. Cell Mol Neurobiol 2002;22: 479-500.

38 Tobet SA: Genes controlling hypothalamic development and sexual differentiation. Eur $\mathrm{J}$ Neurosci 2002;16:373-376.

>39 Becu-Villalobos D, Lux VAR, Lacau-Mengido IM, Libertun C: Sexual differences in the serotoninergic control of prolactin and luteinizing hormone secretion in the rat. Endocrinology 1984;115:84-89.
40 Fitch RH, Cowell PE, Schrott LM, Denenberg VH: Corpus callosum: Perinatal antiandrogen and callosal demasculinization. Int J Dev Neurosci 1991;9:35-38.

41 Van der Schoot P: Disturbed testicular descent in the rat after prenatal exposure to the antiandrogen flutamine. J Reprod Fertil 1992;96: 483-496.

42 McDonald PG, Doughty C: Effect of neonatal administration of different androgens in the female rat: Correlation between aromatization and the induction of sterilization. $\mathrm{J}$ Endocrinol 1974;61:95-103.

43 Becu-Villalobos D, Libertun C: Ontogenesis of $3(\mathrm{H})$ serotonin binding sites in the hypothalamus of the female rat: Relation to serotonin induced $\mathrm{LH}$ release in moxestrol pretreated rats. Dev Brain Res 1986;25:111-116.

44 Saller CF, Czupryna MJ: g-Aminobutyric acid, glutamate, glycine and taurine analysis using reversed-phase high-performance liquid chromatography and ultraviolet detection of dansy chloride derivatives. J Chromatogr 1989;487: 167-172.

45 Schuler V, Luscher C, Blanchet C, Klix N, Sansig G, Klebs K, Schmutz M, Heid J, Gentry C, Urban L, Fox A, Spooren W, Jaton AL, Vigouret J, Pozza M, Kelly PH, Mosbacher J, Froestl W, Kaslin E, Korn R, Bischoff S, Kaupmann K, van der Putten H, Bettler B: Epilepsy, hyperalgesia, impaired memory, and loss of preand postsynaptic GABA(B) responses in mice lacking $\operatorname{GABA}(\mathrm{B}(1))$. Neuron 2001;31:47-58.

46 Brussaard AB, Devay $\mathrm{P}$, Leyting-Vermeulen JL, Kits KS: Changes in properties and neurosteroid regulation of GABAergic synapses in the supraoptic nucleus during the mammalian female reproductive cycle. J Physiol 1999; 516.2:513-524.

47 Schousboe A: Pharmacologic and therapeutic aspects of the developmentally regulated expression of $\mathrm{GABA}(\mathrm{A})$ and $\mathrm{GABA}(\mathrm{B})$ receptors: Cerebellar granule cells as a model system. Neurochem Int 1999;34:373-377.

48 Gorski RA: Hypothalamic imprinting by gonadal steroid hormones. Adv Exp Med Biol 2002;511:57-70.

49 Casto JM, Byron Ward O, Bartke A: Play, copulation, anatomy, and testosterone in gonadally intact male rats prenatally exposed to flutamide. Physiol Behav 2003;79:633-641.

50 Simerly RB: Wired for reproduction: Organization and development of sexually dimorphic circuits in the mammalian forebrain. Annu Rev Neurosci 2002;25:507-536.

51 Panagiotaropoulos T, Pondiki S, Papaioannou A, Alikaridis F, Stamatakis A, Gerozissis K, Stylianopoulou F: Neonatal handling and gender modulate brain monoamines and plasma corticosterone levels following repeated stressors in adulthood. Neuroendocrinology 2004; 80:180-190.

52 Jacobson CD, Csernus VJ, Shryne JE, Gorski RA: The influence of gonadectomy, androgen exposure, or a gonadal graft in the neonatal rat on the volume of the sexually dimorphic nucleus of the preoptic area. J Neurosci 1981;1: 1142-1147. 
53 Davis EC, Shryne JE, Gorski RA: Structural sexual dimorphisms in the anteroventral periventricular nucleus of the rat hypothalamus are sensitive to gonadal steroids perinatally, but develop peripubertally. Neuroendocrinology 1996;63:142-148.

54 De Vries GJ: Minireview: Sex differences in adult and developing brains: Compensation, compensation, compensation. Endocrinology 2004; 145:1063-1068.

-55 Quadros PS, Goldstein AY, De Vries GJ, Wagner CK: Regulation of sex differences in progesterone receptor expression in the medial preoptic nucleus of postnatal rats. J Neuroendocrinol 2002; 14:761-767.

56 Dohler KD, Wuttke W: Changes with age in levels of serum gonadotropins, prolactin, and gonadal steroids in prepubertal male and female rats. Endocrinology 1975;97:898-907.

57 Jakubowski M, Blum M, Roberts JL: Postnatal development of gonadotropin-releasing hormone and cyclophilin gene expression in the female and male rat brain. Endocrinology 1991;128:2702-2708.

58 Ojeda SR and Urbanski HF: Puberty in the rat; in Knobil, Neill J D (eds): The Physiology of Reproduction. New York, Raven Press, 1994, vol. 2, pp 363-409.

59 Debeljuk L, Arimura A, Schally AV: Studies on the pituitary responsiveness to luteinizing hormone-releasing hormone (LHRH) in intact male rats at different ages. Endocrinology 1972;90:585-589.
60 Rao CV, Zhou XL, Lei ZM: Functional luteinizing hormone/chorionic gonadotropin receptors in human adrenal cortical H295R cells. Biol Reprod 2004; 71:579-587.

61 Goodarzi MO, Dawson DW, Li X, Lei Z, Shintaku P, Rao CV, Van Herle AJ: Virilization in bilateral macronodular adrenal hyperplasia controlled by luteinizing hormone. J Clin Endocrinol Metab 2003;88:73-77.

62 Verdonck A, De Ridder L, Kuhn R, Darras V, Carels C, de Zegher F: Effect of testosterone replacement after neonatal castration on craniofacial growth in rats. Arch Oral Biol 1998; 43:551-557.

63 Peets EA, Faye-Henson M, Neri R: On the mechanism of the anti-androgenic action of flutamide (a-a-a- trifluoro-2-methyl-4'-nitro-mpropionotoluidide) in the rat. Endocrinology 1974;94:532-540.

64 Cooke B, Hegstrom CD, Villeneuve LS, Breedlove SM: Sexual differentiation of the vertebrate brain: Principles and mechanisms. Front Neuroendocrinol 1998;19:323-362.

65 Han TM, De Vries GJ: Organizational effects of testosterone, estradiol, and dihydrotestosterone on vasopressin mRNA expression in the bed nucleus of the stria terminalis. J Neurobiol 2003;54:502-510.

66 Luttge WG, Whalen RE: Dihydrotestosterone, androstenedione, testosterone: comparative effectiveness in masculinizing and defeminizing reproductive systems in male and female rats. Horm Behav 1970;1:265-281.

67 Sheridan PJ, Zarrow MX, Denenberg VH: Androgenization of the neonatal female rat with very low doses of androgen. J Endocrinol 1973; 57:33-45.
68 al-Dahan MI, Jalilian Tehrani MH, Thalmann $\mathrm{RH}$ : Regulation of gamma-aminobutyric acidB (GABAB) receptors in cerebral cortex during the estrous cycle. Brain Res 1994;640:33-39.

69 Davis AM, Grattan DR, Selmanoff M, McCarthy MM: Sex differences in glutamic acid decarboxylase mRNA in neonatal rat brain: Implications for sexual differentiation. Hormones and Behavior 1996;30:538-552.

70 Murray HE, Rantle CM, Simonian SX, DonCarlos LL, Herbison AE, Gillies GE: Sexually dimorphic ontogeny of GABAergic influences on periventricular somatostatin neurons. Neuroendocrinology 1999;70:384-391.

71 Davis AM, Grattan DR, McCarthy MM: Decreasing GAD neonatally attenuates steroidinduced sexual differentiation of the rat brain. Behav Neurosci 2000;114:923-933.

72 Romeo RD, Lee SJ, Chhua N, McPherson CR, McEwen BS: Testosterone cannot activate an adult-like stress response in prepubertal male rats. Neuroendocrinology 2004;79:125-132.

73 Davis AM, Ward SC, Selmanoff M, Herbison AE, McCarthy MM: Developmental sex differences in amino acid neurotransmitter levels in hypothalamic and limbic areas of rat brain. Neuroscience 1999;90:1471-1482.

74 Yoo MJ, Searles RV, He JR, Shen W, Grattan DR, Selmanoff M: Castration rapidly decreases hypothalamic g-aminobutyric acidergic neuronal activity in both male and female rats. Brain Res 2000;878:1-10. 